\title{
MAJOR THOROUGHFARE STUDY AND 1990 PLAN FOR COLUMBUS, INDIANA
}

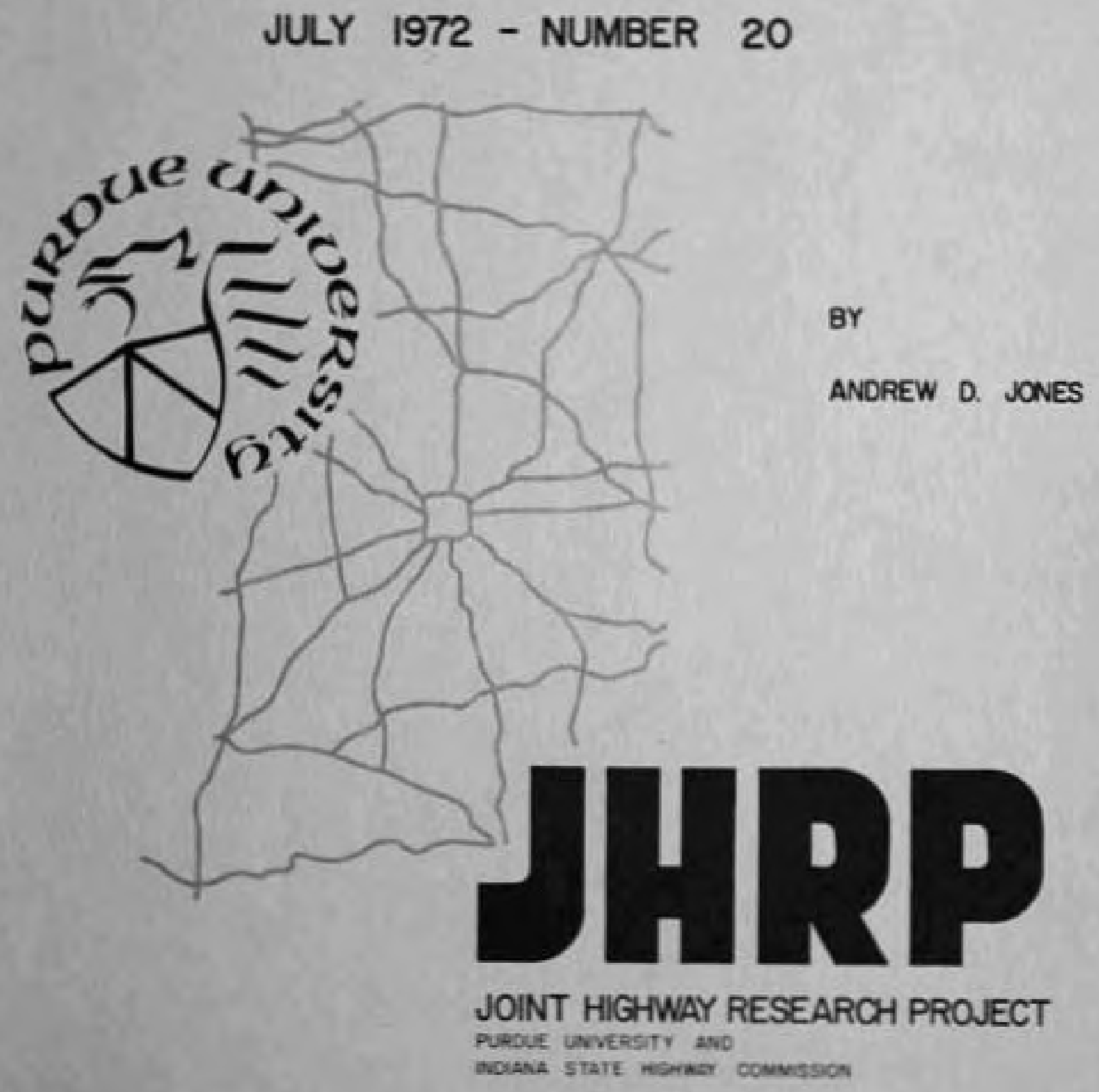




\section{Interim Report}

MAJOR THOROUGHFARE STUDY AND 1990 PLAN FOR COLUMBUS, INDIANA

To: J. F. MeLaughlin, Director

Joint Highway Research Project

FROM: H. L. Michae1, Associate Director Joint Highway Research Project
July 26,1972

Project: C-36-69D

File: $\quad 3-7-4$

The attached Interim Report is a report of a "Major Thoroughfare Study and 1990 P1 an for Columbus, Indiana". It was prepared as a demonstration of the ease with which such a plan can be developed using the simplified planning methods developed in Part V, "Alternate Planning Process for Smal1 Cities", of the HPR, Part I Research Study "An Investigation of the Major Aspects of the Urban Transportation Planning Process".

The Report concludes with a recommended thoroughfare plan for Columbus, recommended design criteria and recommended improvements to the thoroughfare system of Columbus.

The Report is presented for acceptance as partial fulfillment of the objectives of this research. It will be forwarded for review, comment and similar acceptance by ISHC and FHWA.

Respectfully submitted,

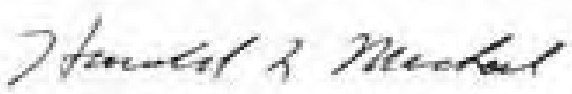

Harold L. Michae 1

Associate Director

HLM:ms

cc: W. L. Dolch

R. H. Harrell

R. L. Eskew

M. L. Hayes

W. H. Goetz

C. W. Love11

W. L. Grecco

G. W. Marks

M. J. Gutzwiller

R. D. Miles

J. W. Miller

C. F. Scholer

M. B. Scott

J. A. Spooner

N. W. Steinkamp

G. K. Hallock

H. R. J. Walsh

E. J. Yoder 


\title{
Interim Report
}

MAJOR THOROUGHFARE STUDY AND 1990 PLAN FOR COLUMBUS, INDIANA

\author{
by \\ Andrew D. Jones \\ Graduate Instructor in Research \\ Joint Highway Research Project \\ Project No.: C-36-69D \\ File No.: 3-7-4 \\ Prepared as Part of an Investigation \\ Conducted by \\ Joint Highway Research Project \\ Engineering Experiment Station \\ Purdue University \\ In cooperation with the \\ Indiana State Highway Commission \\ and the \\ U.S. Department of Transportation \\ Federal Highway Administration
}

The opinions, findings, and conclusions expressed in this publication are those of the authors and not necessarily those of the Federal Highway Administration. 
TABLE OP CONTENTS

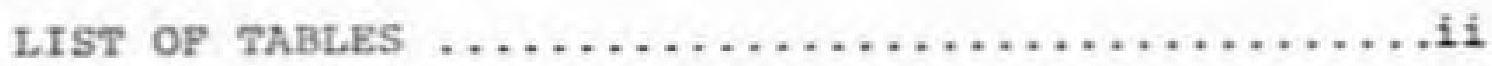

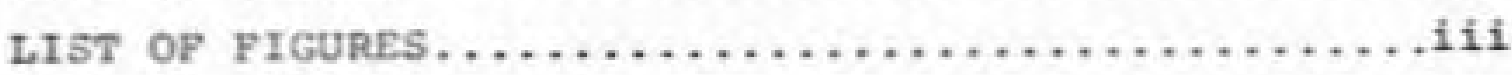

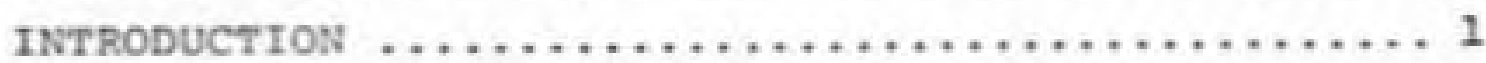

STUDY SCOPE AND OBJECTIVES $\ldots \ldots \ldots \ldots \ldots \ldots \ldots \ldots 4$

PREVIOUS STUDIES AND REPORTS . . . . . . . . . . . 6

POPULATION EAPLOYMENT ECONONICS.......... 8

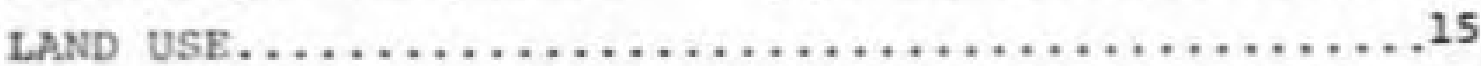

INVENTORY OP EXISTING TRANSPORTATION SYSTEN......19

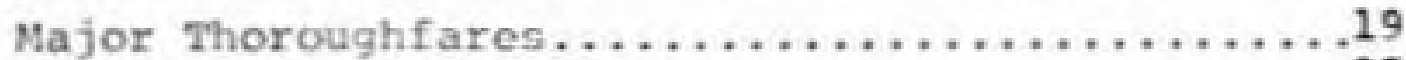

Public Transportation..................25

Accident Study,..................... 28

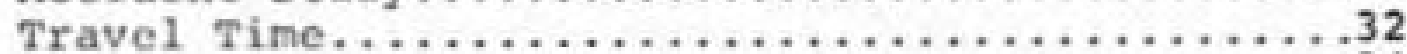

Present and Future Traffic volumes...........34

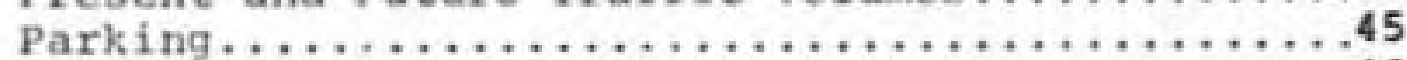

Traffic Control Peatures.................46

LAWS AND ORDINANCES .....................

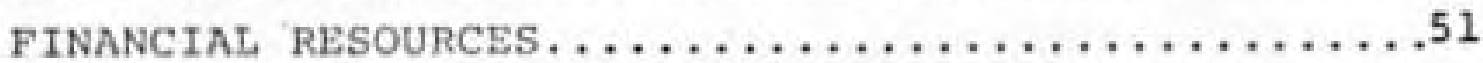

SOCIAL AND COMNUNITY VALUE FACTORS $\ldots \ldots \ldots \ldots \ldots \ldots 54$

ENVIRONMENTAL IMPACT STATEMENT. . . . . $\ldots \ldots \ldots \ldots 56$

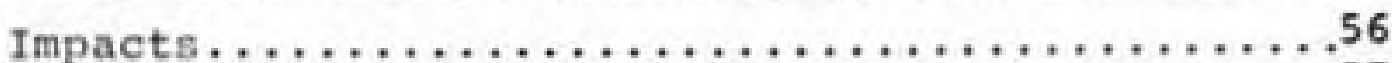

Unavoidable Adverse Affects $\ldots \ldots \ldots \ldots \ldots \ldots \ldots .57$

Alternatives........................

Short and Long Term Effects and Benefits......58

Resources ........................58

DEVELOPMENT OF ALTEPNATE PLANS $\ldots \ldots \ldots \ldots \ldots \ldots \ldots .59$

DEVELOPMENT OF THE MAJOR THOROUGHFARE PLAN $\ldots \ldots \ldots 60$

Recommended Design Criteria..............61

Recommended Improvements................65 


\section{LIST OF TABLES}

\section{Table}

11990 Corridor Data - Columbus.............. 12

2 Pop. - Dwellings - Columbus-1990.......... 13

3 Inventory of Najor Thoroughfares............ 23

4 Intersection Accidents................ 30

5 Columbus - External Cordon Station Check...... 41

6 Columbus - External Cordon Station - 1990....42

7 Radial Corridors - Columbus - Near Central Area43

8 Columbus 1990 Forecast................ 44

9 Estimated Cost for Recommended Improvements Priority for Construction........... 75 
LIST OF FIGURES

Pigure

1 Geographic Location E Study Area Limits -

Colunbus $\ldots \ldots \ldots \ldots \ldots \ldots \ldots \ldots \ldots \ldots \ldots \ldots,{ }^{3}$

2 Columbus Population Projections..............10

3 Columbus Pop. - Dwellings - Zones............14

41970 General Land Use Columbus ..............17

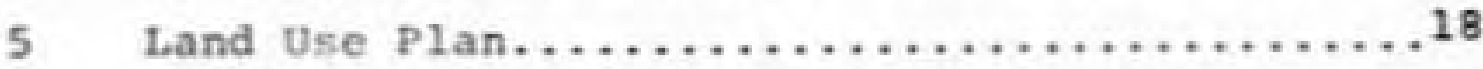

6 Existing Columbus Thoroughfare System........20

7 Columbus - Bus Routes and Coverage..........27

8 Intersection Accident Location............. 29

9 Travel Time............................

101970 ADT Volume Map - Columbus............35

11 Corridors - Columbus.................. 37

12 Corridors - Columbus................. ${ }^{38}$

131960 ADT Volume Map - Columbus............. 39

14 Forecasted volume Map - Columbus.......... ${ }^{40}$

15 Traffic Control Devices on Major Thoroughfares.................. 48

16 Typical Thoroughfare Intersection with Left Turn Provisions....................62

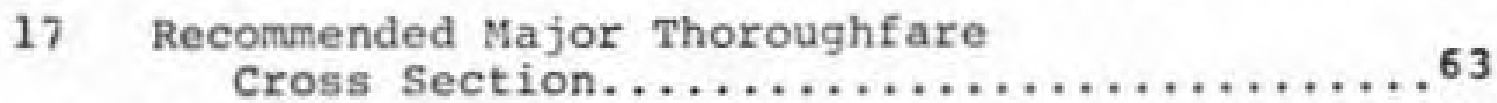

18 Columbus - Recommended Improvements........74 


\section{INTRODUCTION}

Columbus is the county seat of Bartholomew County located approxinately forty miles south of Indianapolis in south-central Indiana.

Columbus is located on U.S. Highways 31 and 31 Alternate with Interstate Highway 65 located just west of the city with several interchanges providing easy access to the city. The city is also served by Indiana Highways 7 and 46 . Bakolar Municipal Airport, north of the city, provides air charter service. The location of the city and access routes are shown on Figure $1 \mathrm{C}$.

The 1970 Bartholomew County population was 57,000 with approximately 27,000 in the city of columbus.

The highly industrialized nature of the city provides a very high ratio of employment to population with a large percentage of the workers commuting fron outside the area. There are five najor industries located in columbus: Cunmins Engine Company, Arvin Industries, Cosco flousehold Products, Reliance Electric Company and the Nead Corporation. The 1970 employment was approximately 21,000.

Columbus is a third class city, operating with a Mayor-Council form of government.

The average annual precipatation in the area is approximately forty inches with an average winter temperature of approximately thirty degrees and an average summer temperature of approximately seventy-six degrees. The city elevation above mean sea level is between six hundred and six hundred-fifty feet. 
The Driftwood River, Flatrock River, llaw Citen and clifty Creek join in the immediate Columbus area to form the East Fork of the White River.

Columbus has shown by its actions that it is concerned with planning for the future. There have been a number of studies and resulting reports providing information necessary for the city administrations to determine the proper course of action. These reports are listed in the list of Previous Studies and Reports in this study and were reviewed in detail in conjunction with this study. 


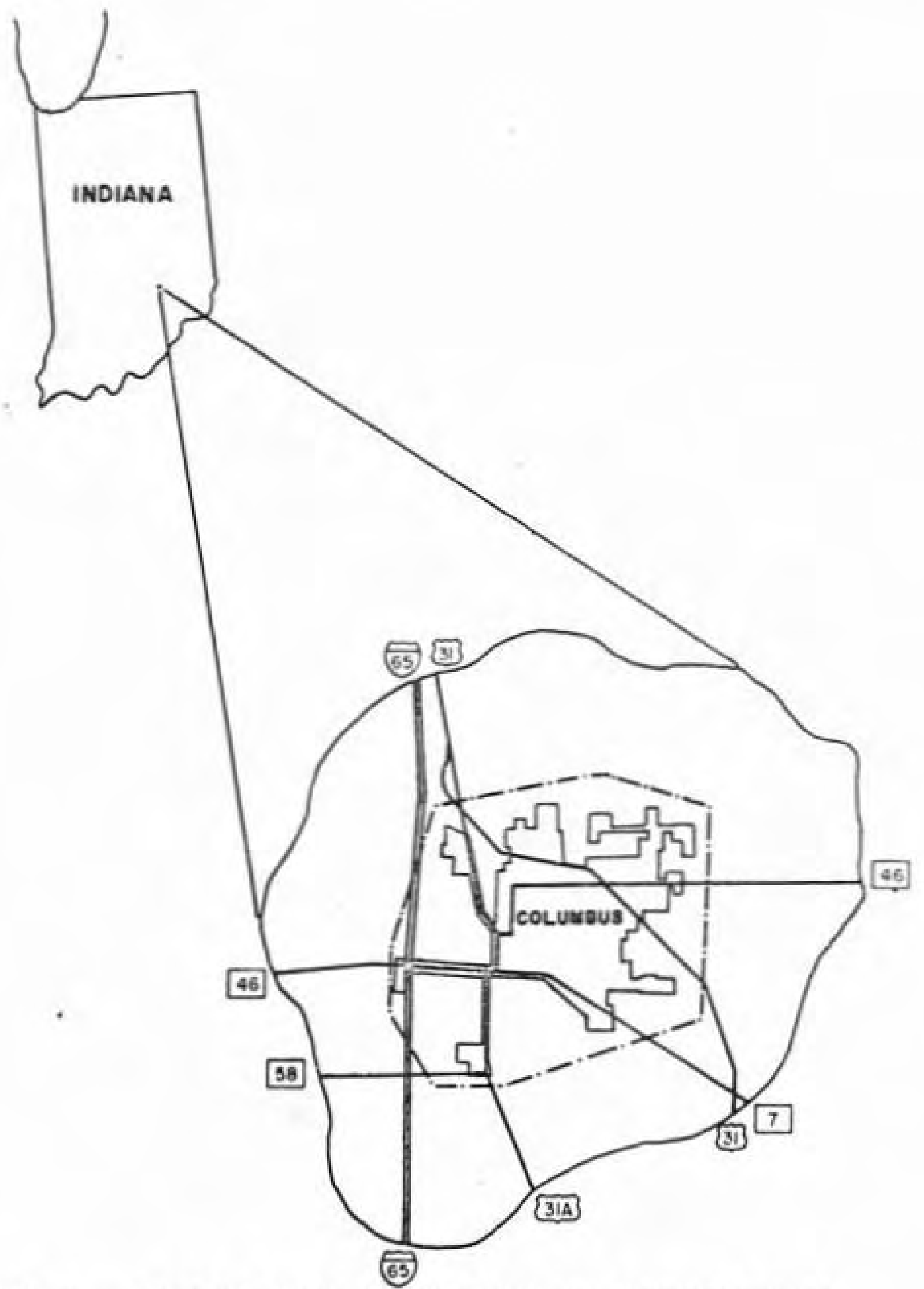

FIGURE I . GEOGRAPHIC LOCATION A STUDY AREA LIIMITS - COLUMABUS 
STUDY SCOPE AND OBJECTIVES

The purpose of this study was to collect the basic information, make necessary forecasts and develop a major thoroughfare plan for Columbus, Indiana using the simplified thoroughfare planning procedure developed at purdue University.

To develop a major thoroughfare plan for an area requires collection of comprehensive data in many areas, evaluating the information and making forecasts of future volumes to the future design or target year for the planning of the thoroughfare system. The major areas requiring collection of data, study and/or forecasts to the future are as follows:

1. Population

2. Land use

3. Physical inventory of the major thoroughfare system

4. Determination of present and future traffic volumes

5. Parking

6. Traffic control features

7. Laws and ordinances pertaining to transportation

8. Financial resources

9. Social and community value factors

10. Development of the major thoroughfare plan

Each of these areas will be discussed in detail in the following pages.

As in all studies, previous studies and reports will furnish much basic data. The reports reviewed and used for 
reference throughout this study are included in the list of Previous Studies and Reports in this report. 
PREVIOUS STUDIES AND REPORTS

The following publications are available in the Columbus City Engineer's office or Office of Director of Planning.

1. Barton-Aschman Associates, Inc., Columbus Central Area Traffic Volumes, December 1970.

2. Barton-Aschman Associates, Inc., A Suggested Circulation Plan and Illustrative Parking Program (for Columbus CBD), January 1969.

3. Chastain, т.н., Columbus Transportation Unpublished Report, Joint Highway Research Project, Purdue University, January 1972.

4. Columbus Area Chamber of Commerce, Industrial Directory.

5. Columbus Plan Commission, Columbus Master Plan, 1949 .

6. Columbus Plan Commission, Columbus Master Plan, 1951.

7. Columbus Plan Commission, Comprehensive Plan -1985, 1967.

8.' Columbus Plan Commission, Proposed General Plan, 1966.

9. Columbus Plan Commission, Thoroughfare Plan ordinance, January 1968.

10. Columbus Plan Commission, Zoning Ordinance, 1971.

11. Columbus Plan Commission, Annual Reports, 1968 , $1969,1970$.

12. DeLeuw, Cather \& Company, Arterial Street Plan, (Columbus, Indiana), 1963. 
13. DeLeuw, Cather \& Company, Parking Needs and Feasibility Study; Bartholomew County llospital, January 1966.

14. Hammer, Greene, Siler Associates, The Housing Crisis in Bartholomew County, Indiana, 1970.

15. Indiana Traffic Safety Survey Team, Traffic Safety Survey; City of Columbus, 1958.

16. 1960 Census, Population and Housing Characteristics, Columbus-Bartholomew County, Indiana.

17. 1970 Census, First Count Data, Bartholomew County, Indiana. 
POPULATION EMPLOYNENT ECONONICS

To provide a basis for future traffic volume forecasts requires a forecast to the desired year of the population growth of the community.

To forecast population of an area requires a historical survey of the past growth, relating this to the regional, state and national growth as a guide. Population growth is directly dependent on economic conditions in an area. To forecast the population growth of Columbus without due regard to an economic forecast would be both futile and foolish. A report prepared by T.H. Chastain, listed under Previous Studies and Reports provided additional factual data on the area economic and employment history.

A review of the 1971 employment for columbus indicates a ratio of approximately two to one for basic to non-basic enployment. The average for most communities is nearer one to two. The total employment for columbus was approximately 22,000 people with approximately 13,000 employed in basic industries. Cummins Engine Company is the largest basic (export) type of industry.

For the simplified procedure for major thoroughfare planning, forecasts of future employment, both the total employment and the retail employment, and the number of dwelling units, by traffic corridors are necessary. The economic growth of the area is a basic input necessary to determine both the magnitude and the location of future growth necessary for traffic forecasting.

This study did not attempt to forecast the economics of the area but instead relied on forecasts made by 
representatives of Indiana University for the Indiana State Planning Commission. This basic information was provided by the Indiana state Planning Commission. The population forecasts in the subject study were for the columbus economic region, encompassing a larger area than needed for this study therefore a means of scaling down was necessary.

The "ratio" method of estimating was utilized for this scaling procedure, using the ratio of the historic trend of population for the city and county to arrive at an estimate of the 1990 city population. The results are presented in Figure $2 \mathrm{C}$.

Figure $2 \mathrm{C}$ also presents a composite of various past population projections indicating the source of the data. Comparing these projections emphasizes the sharp change in the rate of increase experienced in the 1960's as verified by the 1970 U.S. Census.

The Columbus 1985 Master Plan was also referred to extensively during forecasting and distribution of population and employment. The decision was made to base the forecast on the trend established in the 1960's, fully realizing that the trend may not continue. The flexibility and simplicity of the simplified procedure for major thoroughfare planning permits a reasonably economic and fast method of re-evaluating any time a substantial change from the forecast is noted. The Deleuw Cather report was also used for reference in the population distribution process. Table 1C presents the final forecasted values for dwelling units, total employment and retail employment by corridor. Figure $3 \mathrm{C}$ and $\mathrm{Table} 2 \mathrm{C}$ indicate forecasted figures by zones.

The total vehicle registration for Bartholomew County was forecasted by determining the existing ratio of automobiles to population. The forecasted 1990 total vehicles in Bartholomew County, using the same ratio of people to vehicles that existed in 1970, was 47,995 vehicles. 


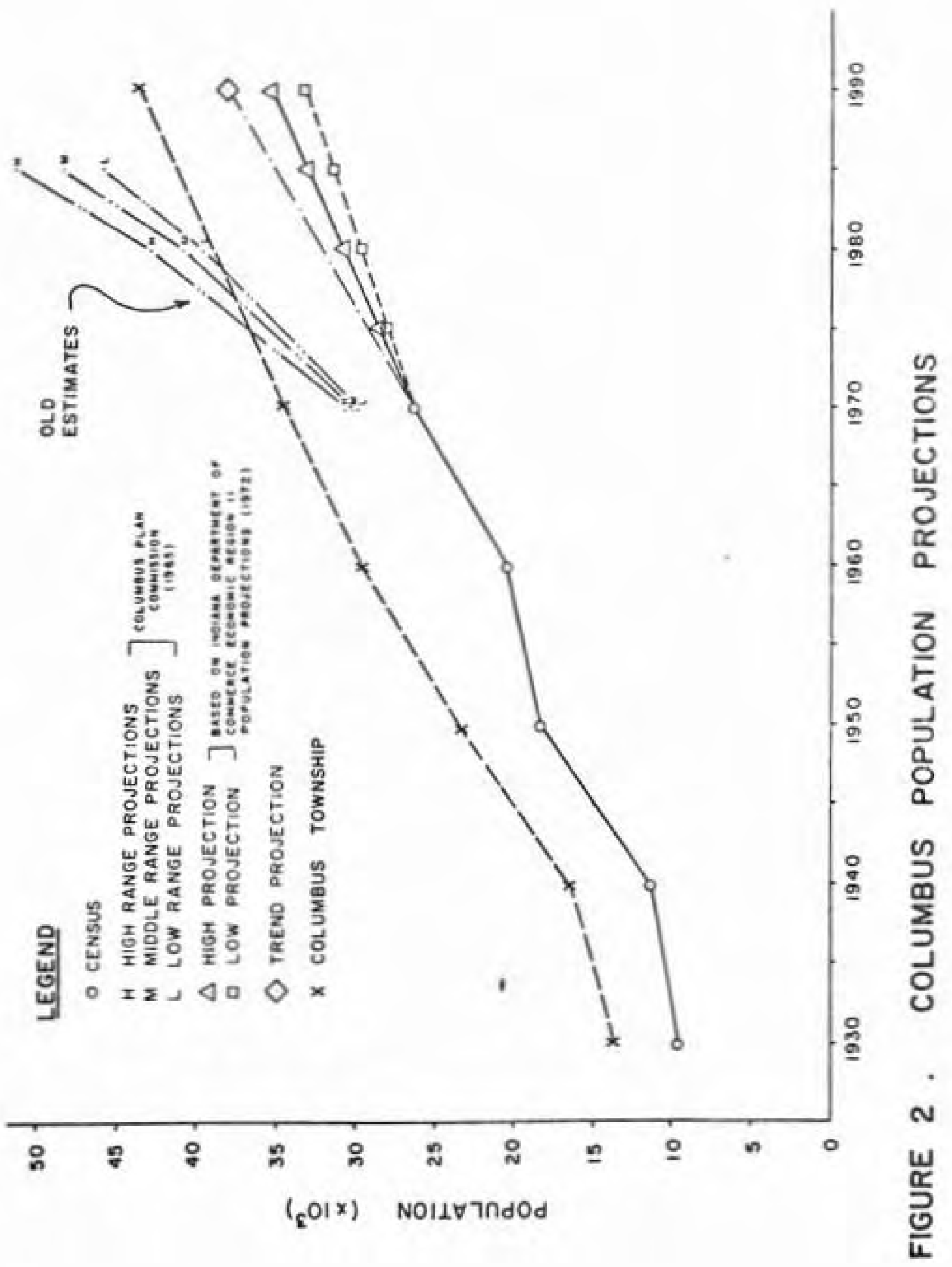


It is anticipated that the city will include the majority of the township by 1990, therefore the forecasted township population was used for the traffic volume forecast. 
Table I 1990 Corridor Data - Columbus

\begin{tabular}{|c|c|c|c|}
\hline Corridor & $\begin{array}{c}\text { Dwelling } \\
\text { Units }\end{array}$ & Employees & $\begin{array}{c}\text { Retail } \\
\text { Employees }\end{array}$ \\
\hline Central Area & 460 & 11,095 & 866 \\
\hline 1 & 647 & 637 & 39 \\
\hline 2 & 233 & 416 & 78 \\
\hline 3 & 697 & 717 & 84 \\
\hline 4 & 2,155 & 5,029 & 566 \\
\hline 5 & 387 & 789 & 23 \\
\hline 6 & 3,153 & 3,414 & 224 \\
\hline 7 & 7,345 & 6,776 & 1,280 \\
\hline $\begin{array}{l}\text { NE Quadrant } \\
\text { (U.S. } 31 \\
\text { Bypass) }\end{array}$ & 8,231 & 8.863 & 1,326 \\
\hline
\end{tabular}


Table 2 Pop. - Dwellings - Columbus - 1990

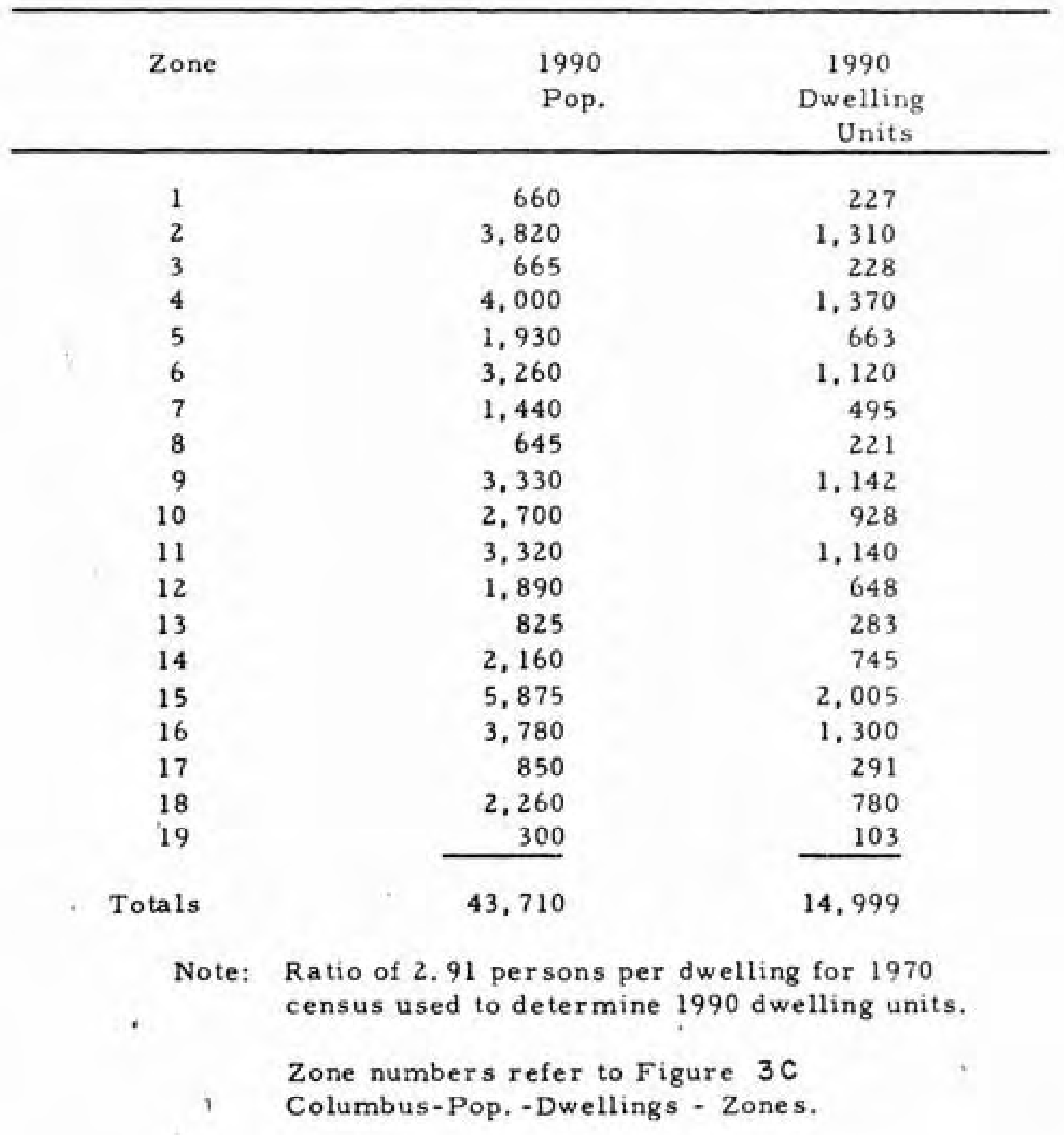




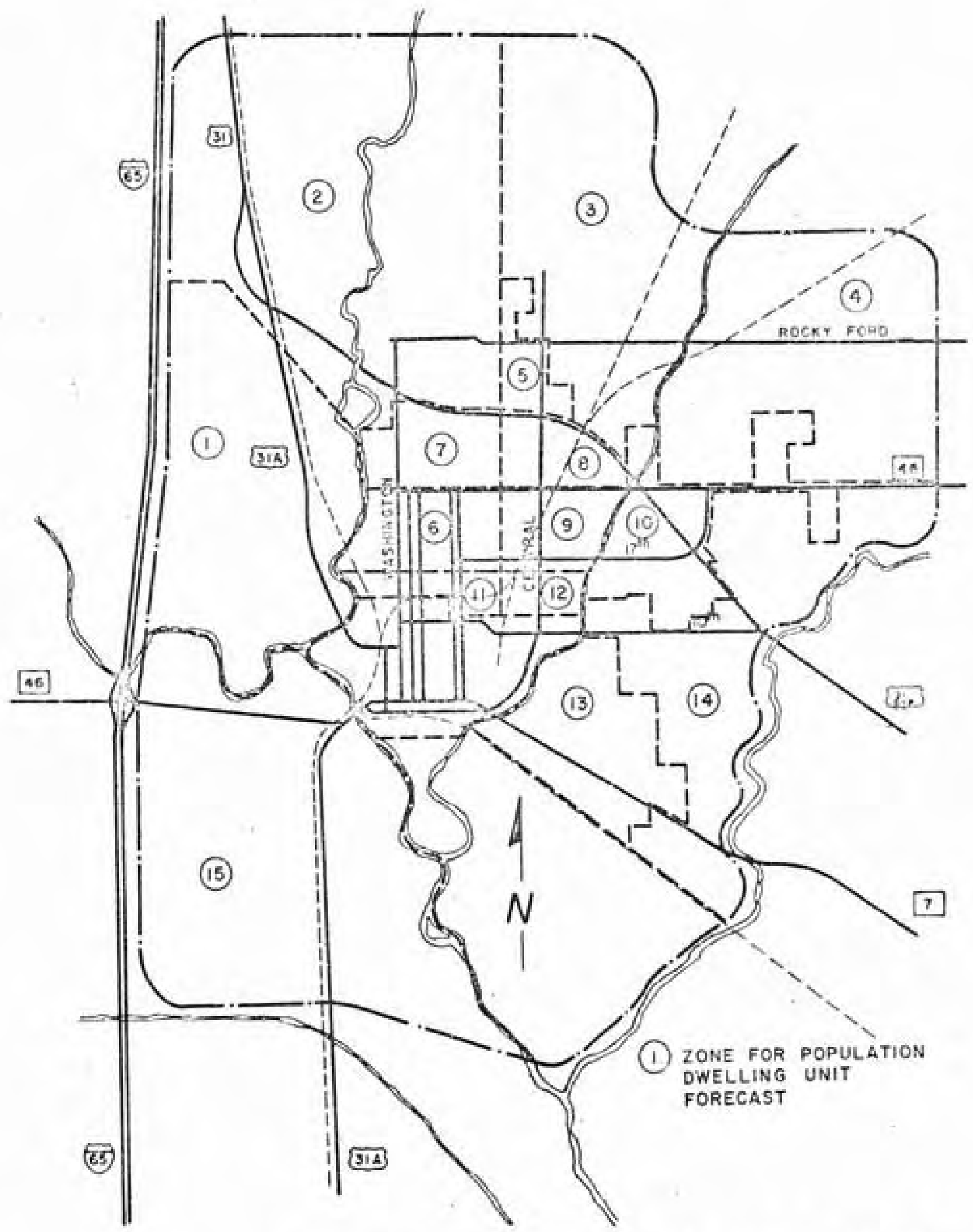

FIGURE 3. COLUMBUS POP-DWELLINGS - ZONES 
LAND USE

To be able to estimate the total number of people that will be in an area at a certain point in time is not sufficient information to permit planning of the transportation system to support and serve these people. The knowledge of the places where they will live, work and play is absolutely necessary.

The individual's selection of a place to live is of course a free choice in our society; however, in the interest of the community as a whole, certain constraints are imposed restricting this freedom. These restrictions, in the form of a master plan and accompaning zoning ordinances and subdivision controls, make it possible to forecast growth patterns with some degree of expected accuracy. The above facilitates the forecast of future traffic volumes subsequent to a land use forecast.

This study utilized the 1985 Master Plan prepared by the Columbus Plan Commission as the datum and extended the forecast to 1990. Adjustments were made based on the revised population forecasts contained herein.

The procedure we follow to derive this information first requires that we know the same items today. The land use inventory and resulting map depicting the location of these uses in the area is completed initially. For Columbus seventeen types of land use were recognized and tabulated. The types were single family dwellings, double family, multi-family dwellings, boarding house and mobile home, commercial, automobile sales and service, wholesalewarehouse, parking, public and non-public buildings, 
agricultural - vacant land, outdoor recreation, heavy manufacturing, light manufacturing, non-manufacturing mineral resource and transportation - commication utilities - railroads. Figure $4 \mathrm{C}$ indicates present land use using four classifications.

The forecasted land use is determined by first allocating the places of forecasted employment to certain areas with the required land area. The new places of residence and commercial centers are subsequently located. In Columbus, the allocation of the future land uses was based on the 1965 Master Plan included in the list of Previous Studies and Reports. The existing land uses and the land use plan are shown in Figures $4 \mathrm{C}$ and $5 \mathrm{C}$.

It should be noted that development of industry in the direction anticipated in the 1985 Master Plan and this study, especially in Corridor 1 , assumes that adequate transportation facilities will be present. If U.S. 31 Alternate or acceptable alternate is not improved, new industry will probably locate elsewhere. 


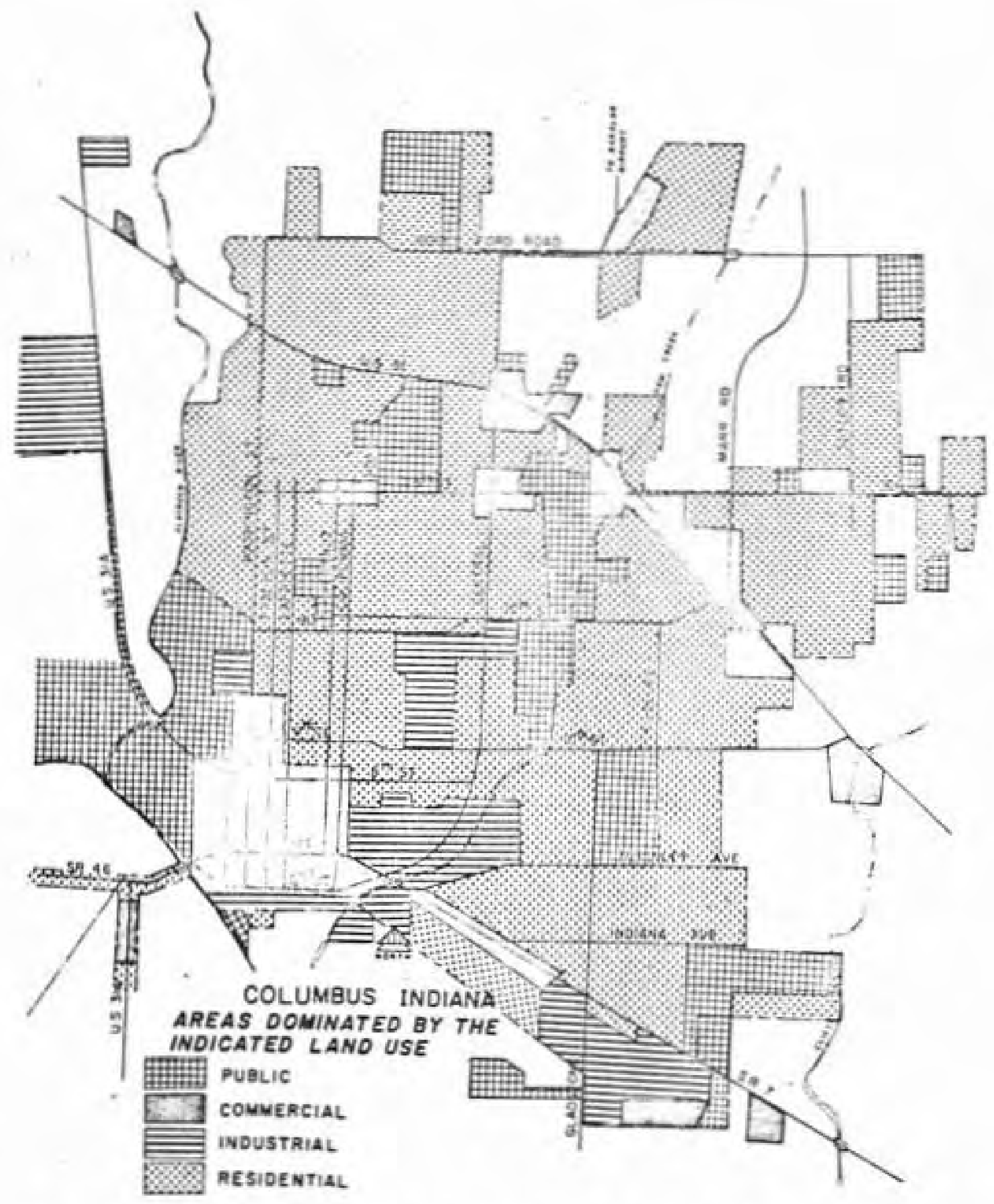

FIGURE 4 . 1970 GENERAL LAND USE COLUMBUS 


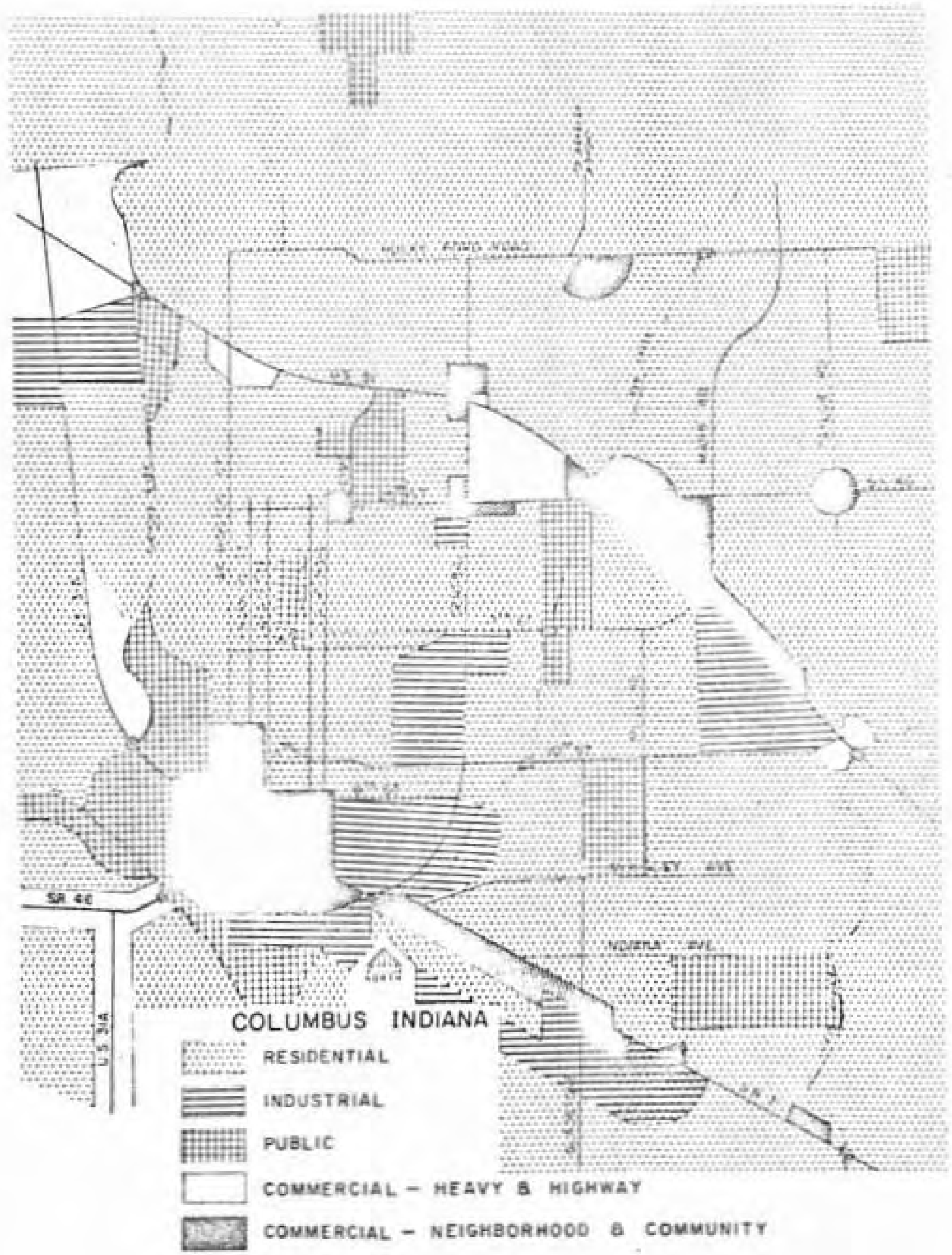

FIGURE 5 . LAND USE PLAN 


\section{INVENTORY OF EXISTING TRANSPORTATION SYSTEM}

\section{Major Thoroughfares}

The street classification presented by the 1968 Thoroughfare Plan-ordinance was the basic system used for the inventory phase of the data collection. All streets classified as primary or secondary arterials were inventoried. Figure $6 \mathrm{C}$ indicates the existing major thoroughfares.

Information collected for the inventory was that information used in the calculation of the capacity or traffic handling capability of the street and information used to evaluate or measure the efficiency of a particular facility.

The data collected is as follows:

1. Street width

2. Number of lanes

3. Parking restrictions

4. Traffic control devices

5. Right-of-way width

6. One-way or two-way

7. Cross section type, curbed, etc.

This information is presented in Table $3 \mathrm{C}$.

The existing street and right-of-way widths were also collected during the study. This information is necessary for use during the development of alternative solutions to the transportation problems. Comparisons of street widths to right-of-way widths provided guidance to the planner when investigating the most economical manner of upgrading the capacity of a particular section, or for determining the 


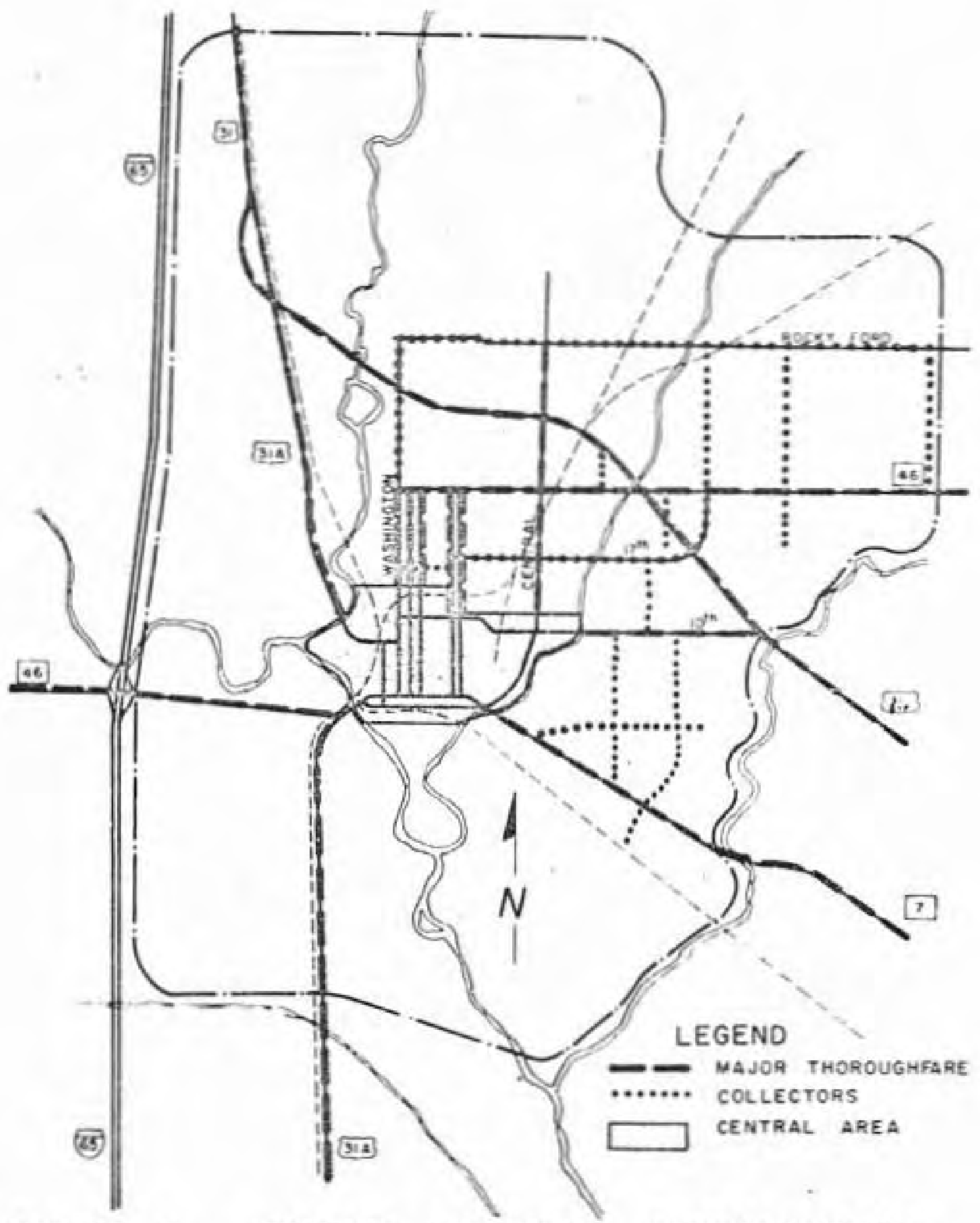

FIGURE 6 . EXISTING COLUMBUS THOROUGHFARE SYSTEM 
need for additional right-of-way etc., to increase tne street width, etc.

The inventory of traffic control devices and parking will be discussed in separate sections of the study.

Theoretical capacities for each street were calculated and are presented in Table 3C. The capacities are expressed as vehicles per hour of green because signal timing is subject to change as conditions on a facility change. The calculated capacities provide a measure of capability of the street to handle traffic and by comparison to existing and forecasted volumes an indication of deficient sections are noted. This information was combined with other inventory data, providing the basis for development of the recommended improvements.

Using a simplified general approach to the evaluation of capacities of thoroughfares would give basically the same results as derived through detailed calculations. Using the 1965 Highway Capacity Manual, acceptable ranges of service volumes were determined assuming the following:

1. A level of service - "C"

2. Population of city $-75,000$

3. Peak hour factor -.85

4. Directional split-60-40

5. Peak hour volume - 10 percent of ADT

6. G/C - .45

7. Lane width - 10-12 feet

8. No parking

9. 20 percent turn

Using these assumptions, considered reasonable for Columbus and verified at spot locations, the following capacity ranges were developed.

4 lane thoroughfare $-12,000-15,000$ vehicles per day

4 lane with left turn lane $-15,000-19,000$ vehicles per day 
6 lane thoroughfare $-19,000-23,000$ vehicles per day

Comparing the estimated 1990 volumes to the service ranges indicates the type of facility required. In Columbus, the only areas where slight overdesign would occur using this procedure would be S.R. 7 at the central area screenline, Twenty-fifth Street at U.S. 31 Bypass and S.R. 46 (W) and U.S. 31 Alternate at the central area screenline. In each of these locations, right turn lanes have increased the capacity over the general service range. This: general procedure is considered acceptable because local personnel would be aware of such additional factors and would adjust accordingly. 
Table 3 Inventery of Major thoreugbiarea and Collectors

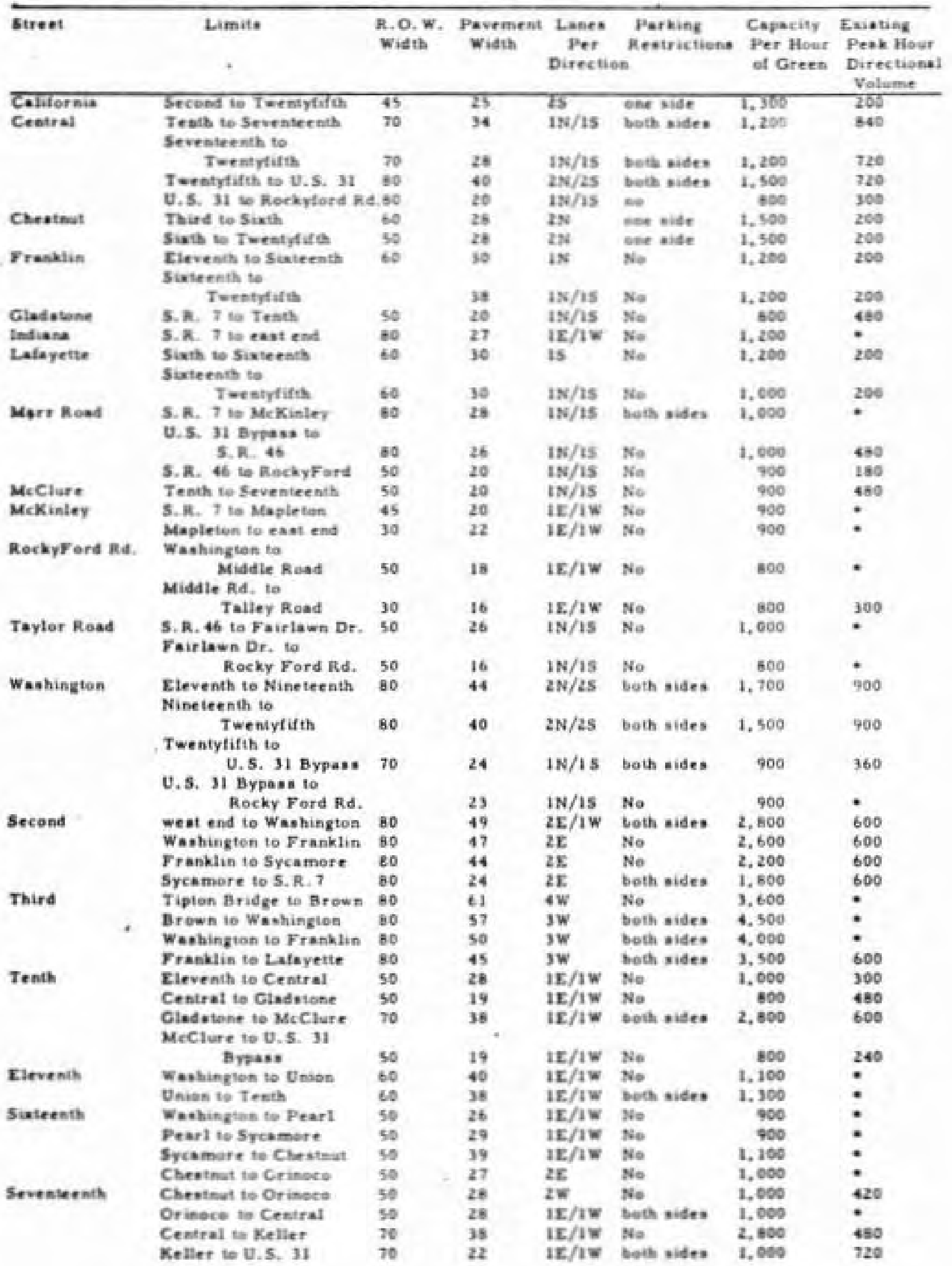


Table 3 cont.

\begin{tabular}{|c|c|c|c|c|c|c|c|}
\hline \multirow[t]{3}{*}{ Streel } & \multirow[t]{3}{*}{ Limita } & \multicolumn{2}{|c|}{ H.O.W, Pavemeat } & \multirow{3}{*}{$\begin{array}{l}\text { Lanes } \\
\text { per } \\
\text { Direction }\end{array}$} & \multirow{3}{*}{$\begin{array}{c}\text { Parking } \\
\text { Restrictions }\end{array}$} & \multirow{3}{*}{$\begin{array}{l}\text { Capheity } \\
\text { Per Hour } \\
\text { of Green }\end{array}$} & \multirow{3}{*}{$\begin{array}{l}\text { Exinting } \\
\text { Peak Hour } \\
\text { Directional } \\
\text { Volume }\end{array}$} \\
\hline & & Width & Wodth & & & & \\
\hline & & & & & & & \\
\hline \multirow[t]{2}{*}{ Twentyfifth } & $\begin{array}{l}\text { Washington fo Central } \\
\text { Central to U, } 5,31\end{array}$ & 60 & 48 & $2 \mathrm{E} / 2 \mathrm{~W}$ & both sides & 1.800 & 1.200 \\
\hline & Bypass & 90 & 48 & $2 E / 2 W$ & both sides & 1,800 & 740 \\
\hline S.R. 7 & Second to Marr Road & BO & 52 & $2 E / 2 W$ & both sides & 1,800 & 1,000 \\
\hline \multirow[t]{2}{*}{ S.R. 46} & 1.65 to U.5. 31 Aliternate & $\operatorname{te} 60$ & 30 & $1 E / 1 W$ & No & 1,000 & 770 \\
\hline & U.S. 31 to Talley $\mathrm{kd}$. & 70 & 44 & $2 \mathrm{E} / 2 \mathrm{~W}$ & No & 1.200 & 735 \\
\hline \multirow[t]{2}{*}{ U.S. 31} & $\begin{array}{l}\text { U.S. } 31 \text { Atternate to } \\
\text { Washington } \\
\text { Washington te Clifty }\end{array}$ & 120 & 23 & $1 \mathrm{~N} / 1 \mathrm{~s}$ & No & 800 & 590 \\
\hline & Creek Bridge & 100 & 23 & $1 \mathrm{~N} / 1 \mathrm{~S}$ & No & 800 & 720 \\
\hline & $\begin{array}{l}\text { U.S. } 31 \text { to Eighth } \\
\text { S.A. } 46 \text { to Denois }\end{array}$ & 80 & 24 & $1 \mathrm{~N} / \mathrm{iS}$ & No & 600 & 370 \\
\hline$\therefore$ & Creek & 80 & 26 & $1 \mathrm{~N} / 1 \mathrm{~S}$ & No & 800 & 615 \\
\hline
\end{tabular}

Counts Not Available

Nole: Figures in this table are taken from aerial photas. 


\section{Public Transportation}

Any transportation or thoroughfare plan must recognize and evaluate the role played by public transportation in the community. Columbus is served by four city owned and operated "mini" buses, with capacities of approximately twelve passengers each. Three buses are required to serve the routes and areas shown in Figure $7 \mathrm{C}$. One bus is used for standby. Two of the buses operate on half-hour headways throughout the day. The third bus is used to provide one hour service on the remaining routes.

The useage of the service was checked in November 1971. The Everroad Park and Forest Park bus served an average of fifty-six adults and eight children per day. The East Columbus route served seventy-seven adults and nineteen children while the Eastgate route provided service to eighty-six adults and thirty-three children per day.

The service provided by this procedure generally meet the criteria established by the National Committee on Urban Transportation. The large residential areas, major shopping center, public facilities and industries are served by the routes assuming coverage to be one-fourth mile either side of the actual route. Discussions with the city authorities indicate the seats to passenger ratio to be satisfactory at al1 times.

Many transportation experts view public transportation such as these buses as a public service, serving a segment of the general public that may be designated as captive users. The majority of those using buses in all communities are those people either too old or too young, physically handicapped or financially unable to afford other types of transportation. Brief observations of the system substantiates this factor for columbus. The high percentage of children tabulated as daily users also confirms this fact. 
Few public transportation systems in the country provide reasonable service and show a profit and Columbus is no exception. The present ridership and fare structure are not designed to show a profit. Considering the service in the same light as other community services, police and fire protection, etc., it should be continued with active proper management. 


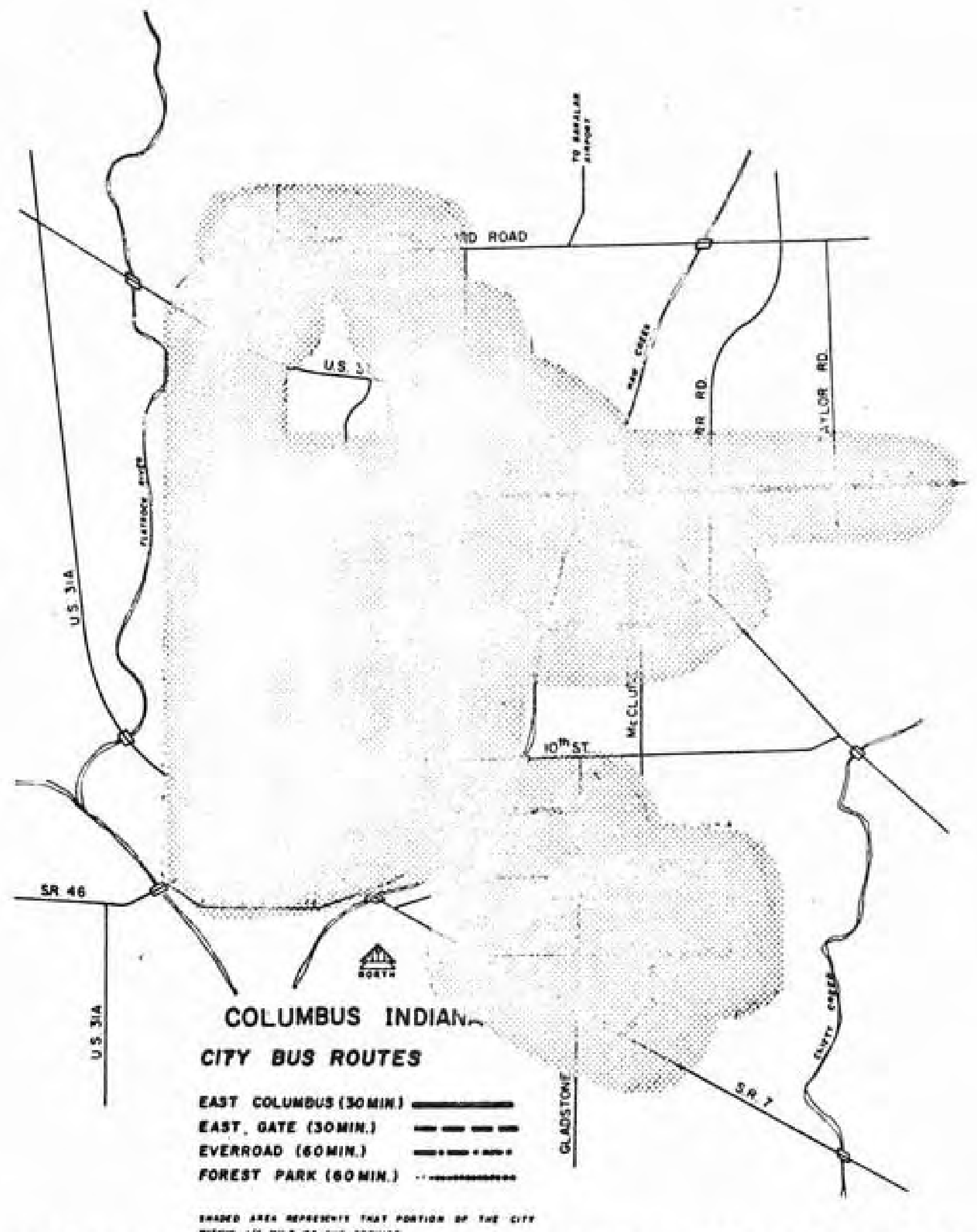

FIGURE 7 . COLUMBUS-BUS ROUTES AND COVERAGE 


\section{Accident Study}

Traffic accidents are an undesirable by-product of vehicular traffic and can be used to evaluate how well a thoroughfare system is functioning. To properly review records of traffic accidents and draw proper conclusions requires assembling the accident records for a three to five year period. This provides a means of averaging the accidents over the period to give a better indication of the conditions at a particular intersection. When the number of accidents, the type of accident and the existing traffic volume at a particular intersection are studies together a means of comparative evaluation throughout the system is provided. A high accident rate at an intersection may indicate improper design or control.

Figure $8 \mathrm{C}$ indicates the number of accidents on the Columbus system in 1970. Table 4C provides a ten year accident history for the Columbus thoroughfare system.

The accident rates for the major thoroughfare system were evaluated during the plan development phase of the study. 


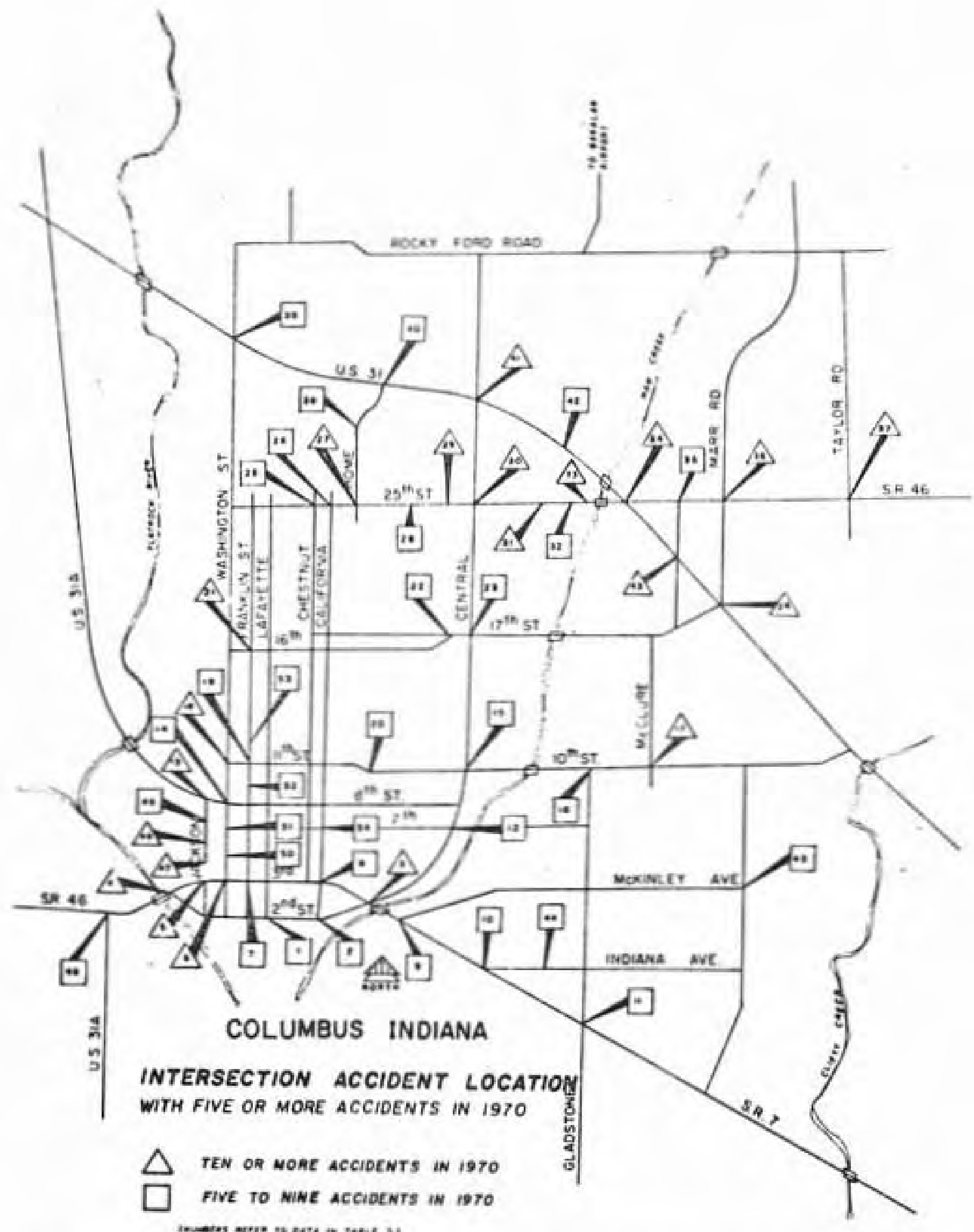

FIGURE 8 . INTERSECTION ACCIDENT LOCATION 


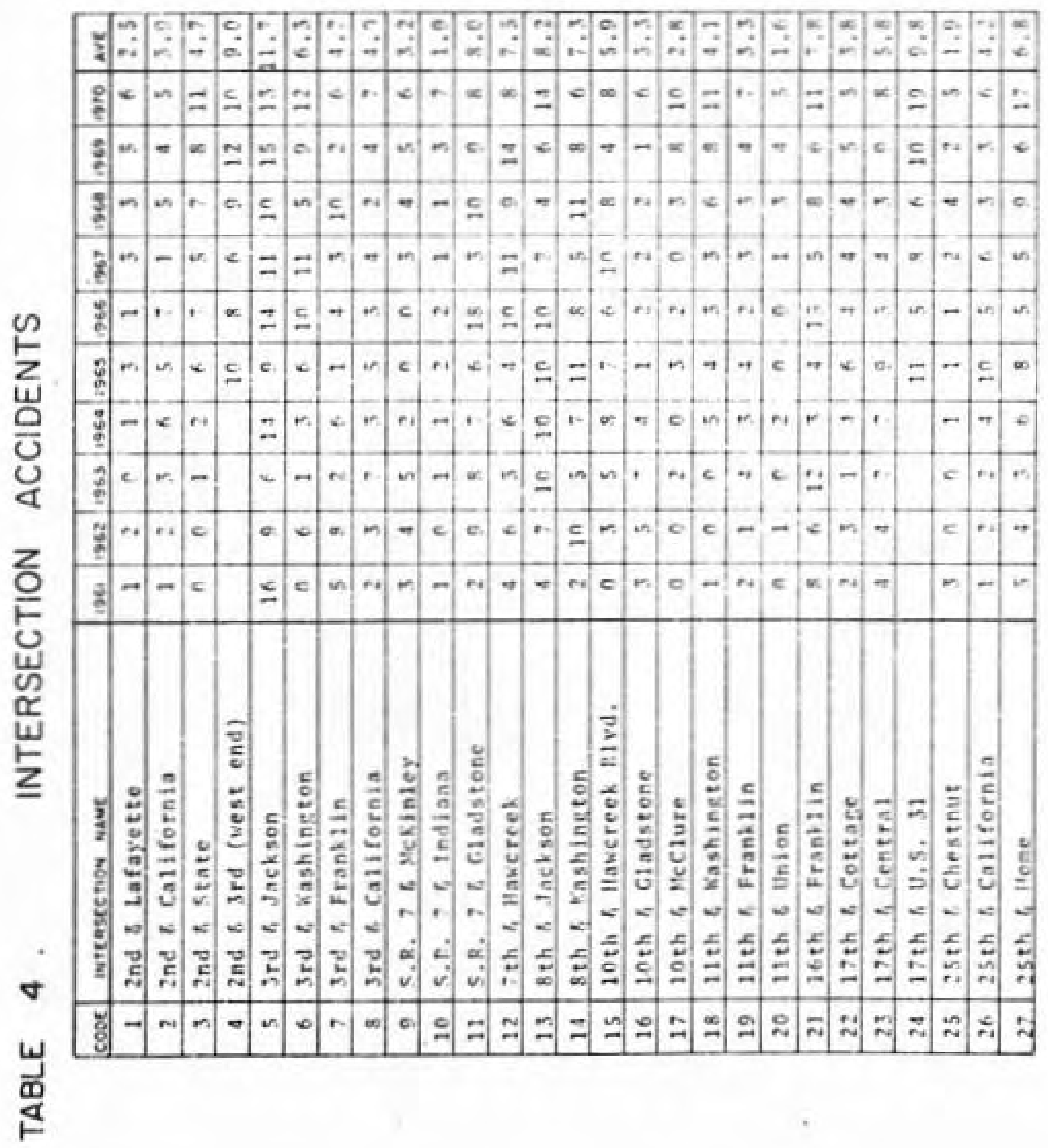




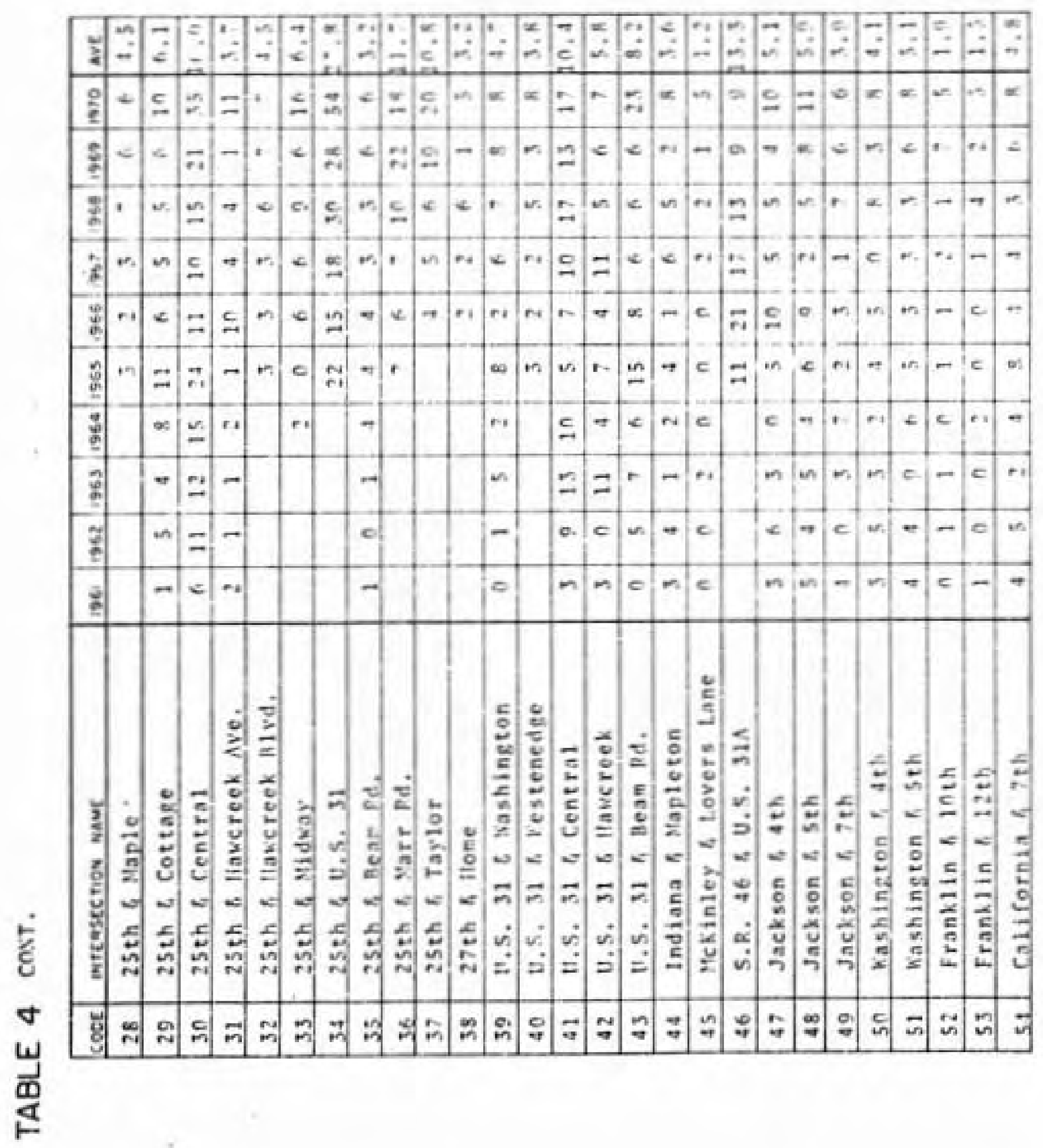




\section{Travel Time}

Travel times during peak and off-peak periods in each corridor were obtained and are presented in Figure 9c.

Travel times are one measure used to determine the level of service and efficiency of the street system. The information thus obtained was combined with the accident rate, existing and forecasted volumes, available capacity, etc., to determine deficient sections of the system needing improvement.

The travel times indicate relatively free traffic flow in the west, south and southeast sectors of the city on U.S. 31 Alternate ( $\mathrm{N}$ and S), S.R. 46 and S.R. 7. Central Avenue and Twenty-fifth Street indicate much slower travel times. The peak hour travel time over the Twenty-fifth street and Washington street route, from the central area to Talley Road, was approximately four minutes slower during the afternoon peak than during off-peak. The same observation applies to Central Avenue. Signalized intersections on Twenty-fifth Street at U.S. 31 Bypass and on Central Avenue at Seventeenth Street are the main points of delay. 


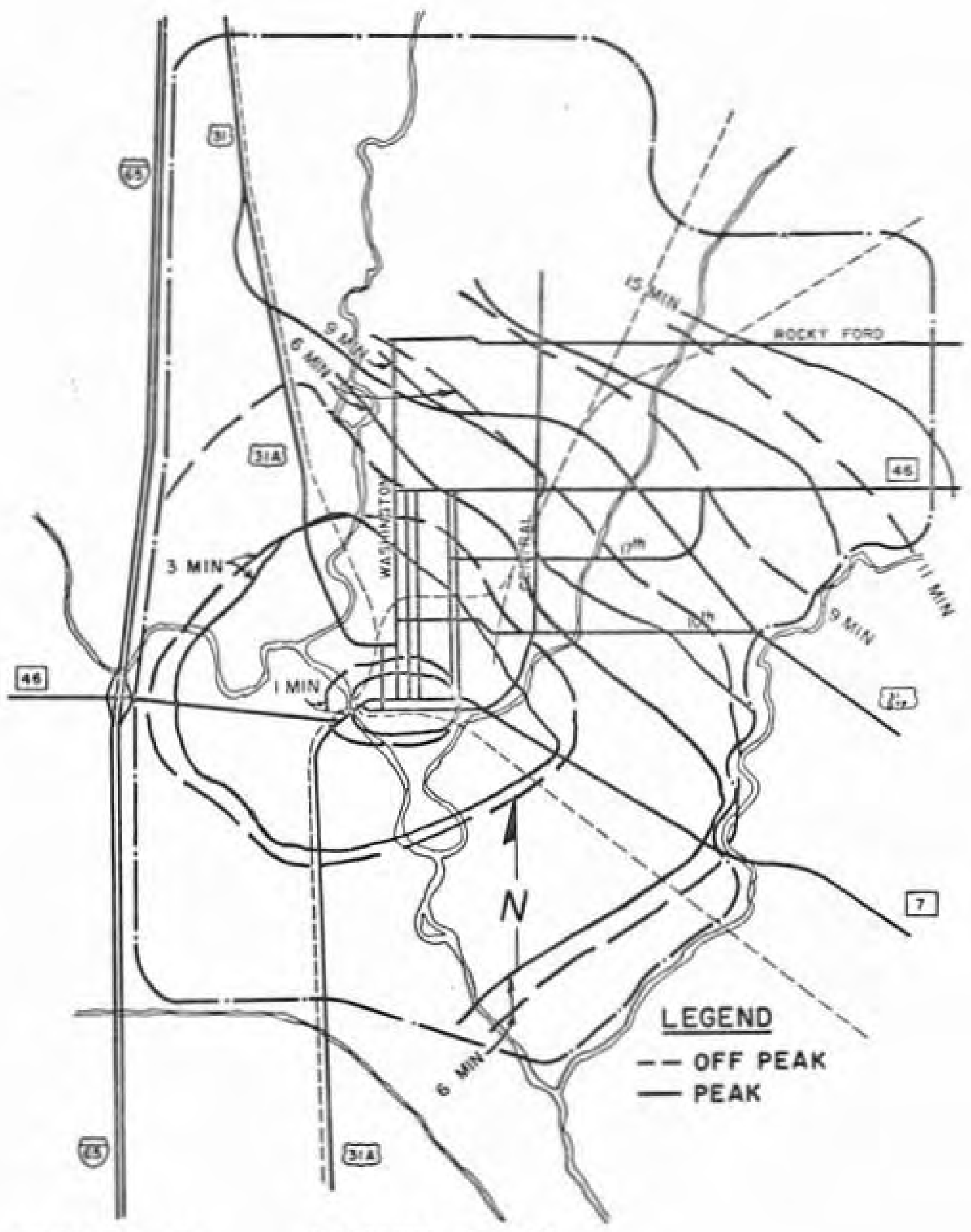

FIGURE 9 . TRAVEL TIME 


\section{Present and Future Traffic Volumes}

To plan adequately for the future requires estimates of future traffic volumes derived from forecasts of the magnitude and direction of growth in a community. These future volumes provide a quantitative measure for planning the future major thoroughfare system of columbus.

Research has shown that in communities such as Columbus, the travel patterns, both internal and external are well established. The direction of growth has been previously established as well as the trends. The study of traffic involves establishing a point on a continuum, not a new starting point; therefore, growth factor expansion is a valid economical procedure, producing results completely adequate for major thoroughfare planning.

Existing traffic volumes were determined at many points throughout the city on the thoroughfares and collectors. The Indiana State Highway Comnission and the Columbus City Engineer's office were the source of the count data. T.H. Chastain's report entitled "Columbus Thoroughfares" presented this information in tabular form. Figure $10 \mathrm{C}$ presents this information in the form of a volume flow map.

Traffic volumes on the system for 1990 provide the required design volumes for planning. These future volumes for columbus were determined using the "corridor growth factor" technique developed by the Joint Highway Research Project at Purdue University. The procedure uses the growth of three parameters to represent the total trips in a traffic corridor using them to compute a growth factor to apply to the existing traffic volume thus providing a future volume.

The entire procedure is designed to permit and encourage major thoroughfare planning by the technical personnel already available in the city administration. The use of 


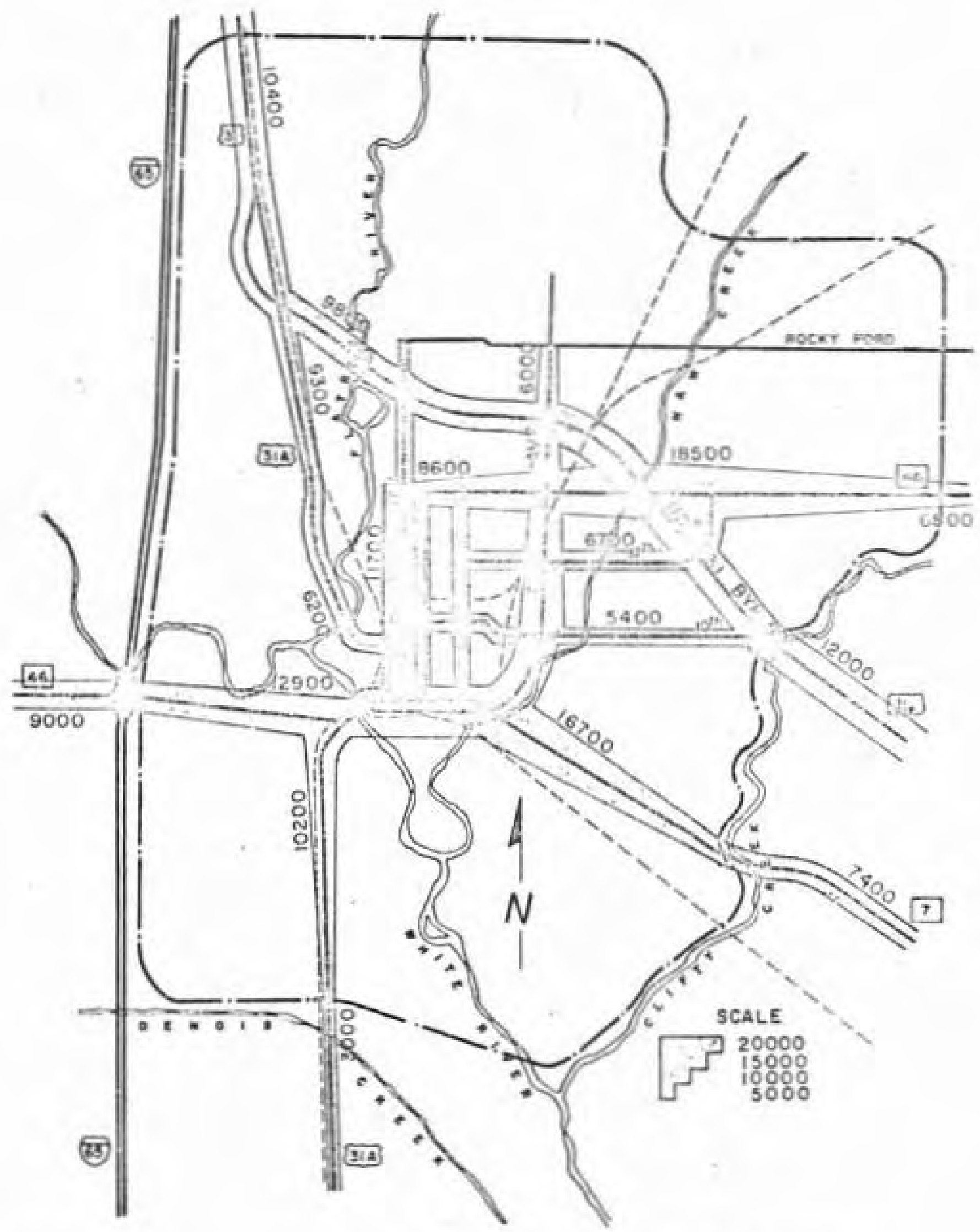

FIGURE 10.1970 ADT VOLUME MAP-COLUABUS 
computers was not required. The data collection is minimal and a large portion of the material was obtained from uncontrolled aerial photography available at reasonable prices.

The number of dwelling units, total number of employces and total number of retail employees, retail being designated as those employed by firms with S.I.C. codes of 5250 to 5460 and 5540 to 5990 , per traffic corridor was collected for 1960 and 1970. Forecasts were made using two digit classifications. The corridor growth factor was calculated for each corridor for the calibration period of 1960 to 1970 and was applied to the 1960 traffic values. After corridor limits were adjusted to satisfactorily duplicate the 1970 traffic volumes, the same procedure provided design volumes for 1990 using forecasted parameters for growth factor calculation. The corridors, 1960-1970 calibration, 1960 and 1970 traffic volumes, and the forecasted traffic volumes are shown on Figures $10 \mathrm{C}-14 \mathrm{C}$ and Tables 5c-8c respectively. The corridor values for the parameters are given in Table $1 \mathrm{C}$.

External traffic volumes were similarly expanded. A growth factor based on the increase in vehicle registration for Bartholomew County was computed. The growth factor was applied to the 1960 traffic volume at each major thoroughfare crossing of the study area cordon. This was compared to the 1970 existing volume to verify the adequacy of the parameter. The vehicle registration increase for the county to 1990 provided the growth factor for expansion of all external traffic to the design year. 


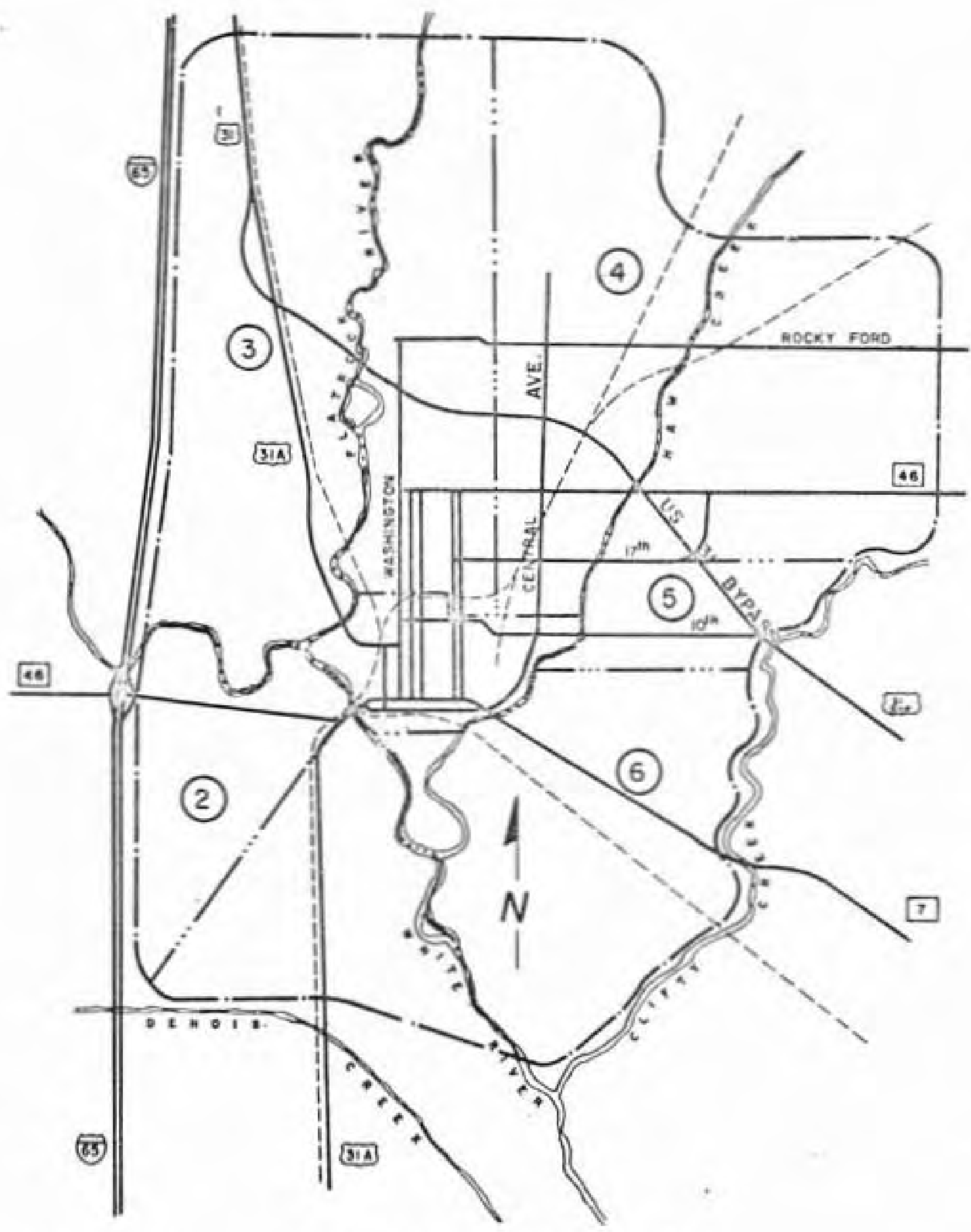

FIGURE II. CORRIDORS-COLUMBUS 


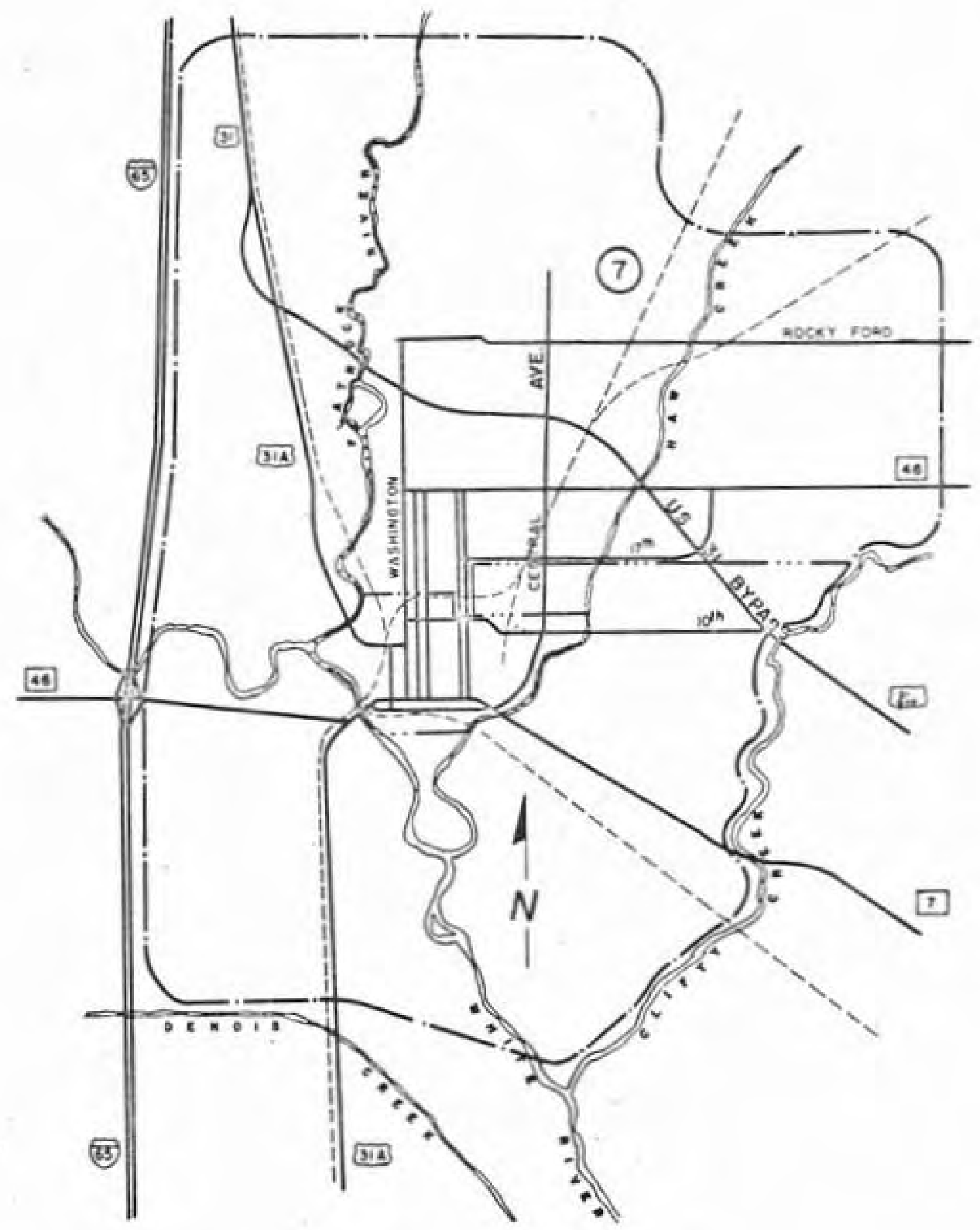

FIGURE 12. CORRIDORS-COLUMBUS 


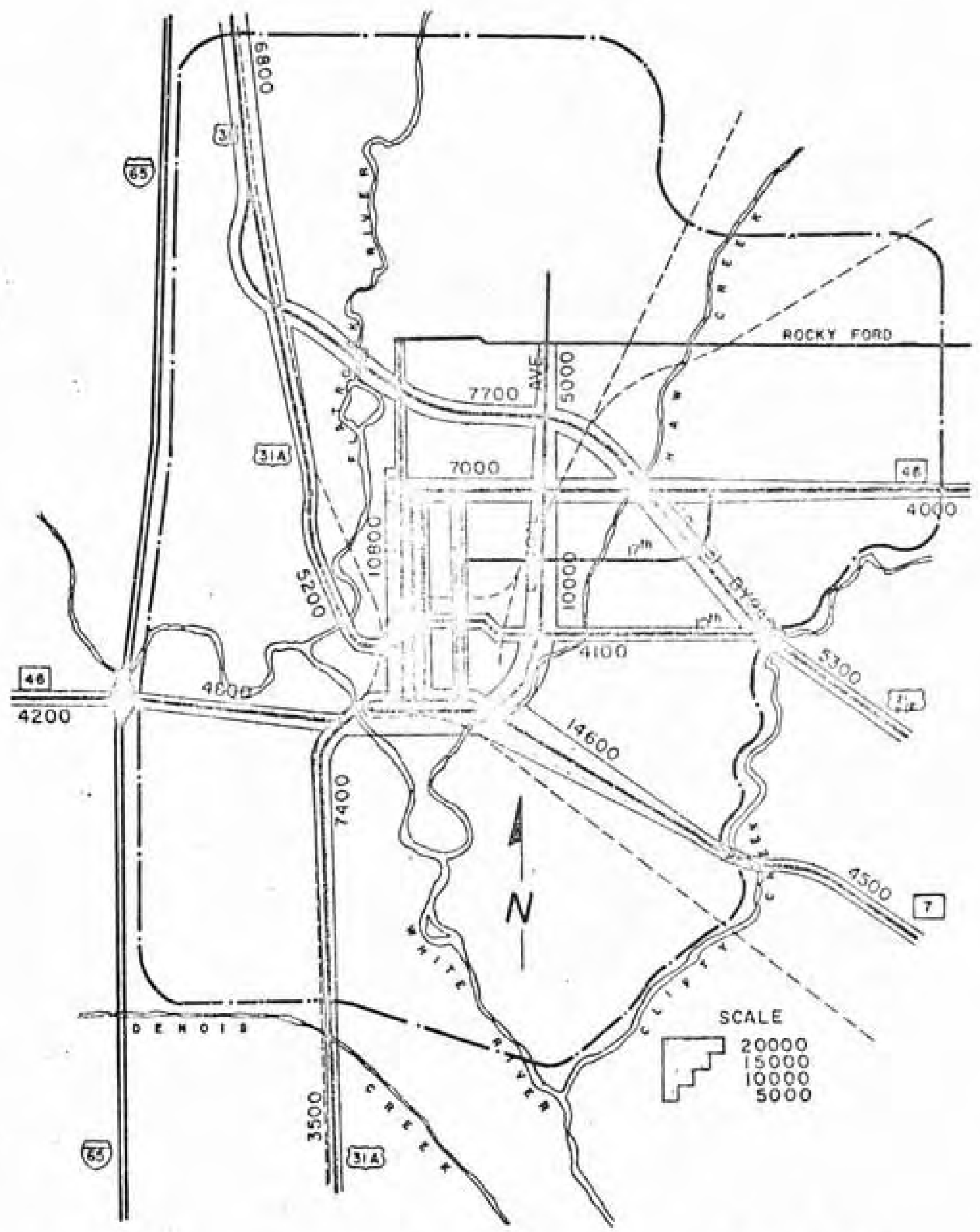

FIGURE 13 . 1960 ADT VOLUME MAP-COLUMBUS 


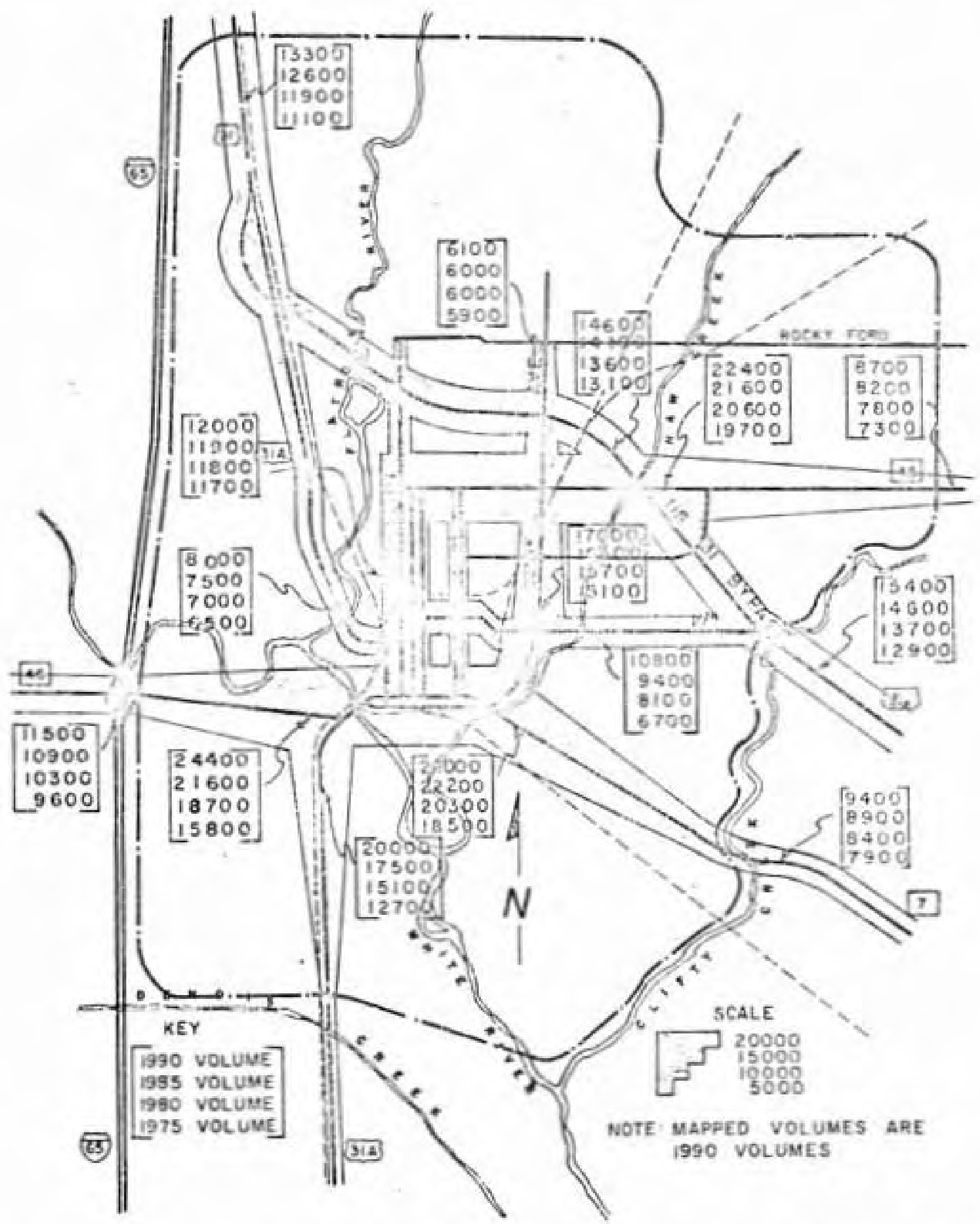

FIGURE 14 . FORECASTED VOLUME MAP-COLUMBUS 
Table 5 Columbus - External Cordon Station Check

\begin{tabular}{lclccc}
\hline Route & 1960 & Growth & Estimated & Actual & Error \\
& Vol. & Factor & 1970 & 1970 & \\
& & & Volume & Volume & \\
& & & & & \\
\hline
\end{tabular}

$\begin{array}{llllll}\text { U.S. } 31(\mathrm{~N}) \quad * \quad 6,858 & 1.64 & 11,247 & 10,399 & 848 \\ \text { S.R. } 46(\mathrm{E}) & 3,956 & 1.64 & 6,488 & 6,816 & -328\end{array}$

U.S. 31 Bypass

at Clifty Creek * $5,325 \quad 1.64 \quad 8,733 \quad 12,034 \quad-3,301$

S.R. 7 at

Clifty Creek

$4,522 \quad 1.64 \quad 7,416 \quad 7,371$

45

U.S. 31 Alt. at Denois Creek

$3,562 \quad 1.64 \quad 5,842 \quad 3,052 \quad 2,790$

S.R. $46(W)$

$$
4,200 \quad 1.64 \frac{6,888}{46,614} \frac{9,011}{48,683}-2,123
$$

* Existing volumes reduced $30 \%$ to adjust for opening of 1.65 as per Arterial Street Plan for Columbus, Indiana (9). 
Table 6 Columbus-External Cordon Stations - 1990

\begin{tabular}{lccc}
\hline Route & $\begin{array}{c}1970 \\
\text { Volume }\end{array}$ & $\begin{array}{c}\text { Growth } \\
\text { Factor }\end{array}$ & $\begin{array}{c}\text { Forecasted } \\
1990 \\
\text { Volume }\end{array}$ \\
\hline U.S. 31(N) & 10,399 & 1.28 & 13,311 \\
S.R. 46 (E) & 6,816 & 1.28 & 8,724 \\
$\begin{array}{l}\text { U.S. 31 Bypass } \\
\text { at Clifty Creek }\end{array}$ & 12,034 & 1.28 & 15,404 \\
$\begin{array}{l}\text { S.R. 7 at } \\
\text { Clifty Creek }\end{array}$ & 7,371 & 1.28 & 9,435 \\
$\begin{array}{l}\text { U.S. 31 Alt. at } \\
\text { Denois Creek }\end{array}$ & 3,052 & 1.28 & 3,907 \\
S.R. 46(W) & 9,011 & 1.28 & 11,534
\end{tabular}




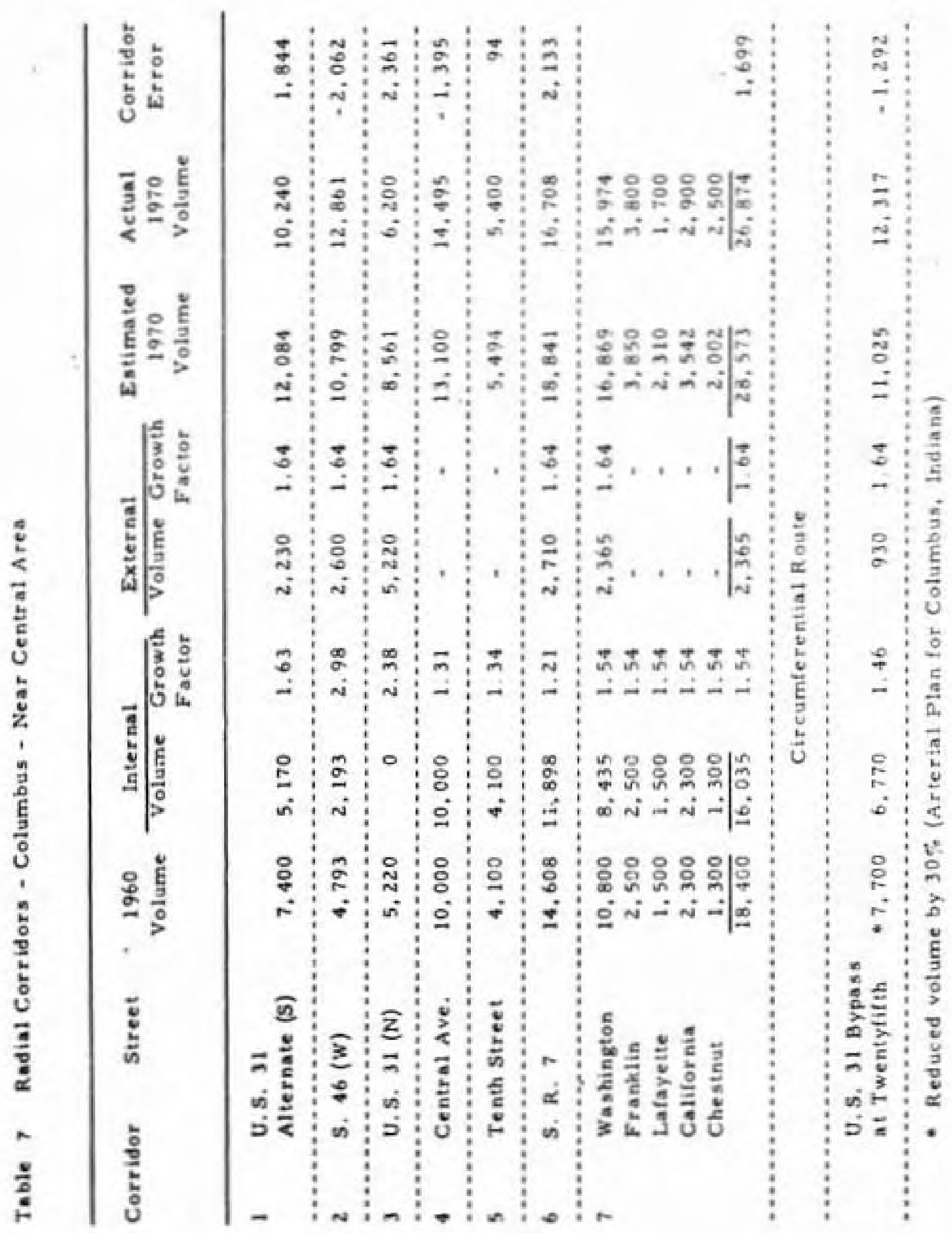


Table 8 Columbus - 1990 Forecast

\begin{tabular}{|c|c|c|c|c|c|c|c|}
\hline \multirow[t]{2}{*}{ Corridor } & \multirow[t]{2}{*}{ Street } & \multirow{2}{*}{$\begin{array}{c}1970 \\
\text { Volume }\end{array}$} & \multicolumn{2}{|c|}{ Internal } & \multicolumn{2}{|c|}{ Extersal } & \multirow{2}{*}{$\begin{array}{c}\text { Estimated } \\
1990 \\
\text { Volume }\end{array}$} \\
\hline & & & Volume & $\begin{array}{l}\text { Growth } \\
\text { Factor }\end{array}$ & Volume & $\begin{array}{l}\text { Growth } \\
\text { Factor }\end{array}$ & \\
\hline
\end{tabular}

1 U.S. 31 Alternate
(S)
$10,240 \quad 8,530$
2. 06
1. 710
1,28
19,761$$
2
$$

2

S. R, $46(W)$

$12,860 \quad 7,400$

2. 35

5,460

$1.28 \quad 24,379$

$$
3
$$

U.S. $31(\mathrm{~N})$

6,200

410

1. 48

5. 790

1.28

8,018

$$
4
$$

Central Avenu

$14,495 \quad 14,495$

1.17

16,959$$
5
$$

$$
5
$$

Tenth Street

5, $400 \quad 5,400$

2. 00

10,800

$$
6
$$$$
7
$$

S. R. 7

$16,708 \quad 12,498$

1. 49

4,210

1.28

24, 011

7 Washington

Franklin

$15,974 \quad 12,164$

1.19

3, 810

1. 28

19.352

Lafayette

$3,800 \quad 3,800$

1. 19

1, $700 \quad 1,700$

1. 19

2, $900 \quad 2,900$

1. 19

Chestnut

$\frac{2,500}{26,874} \quad \frac{2,500}{23,064}$

1. 19

1. 19

-

-

4, 522

2,022
3,451

$\frac{26,874}{23,064}$

$\frac{.}{3.810}$

$-$

$\frac{2.975}{32,322}$

\section{C ircumferential Route}

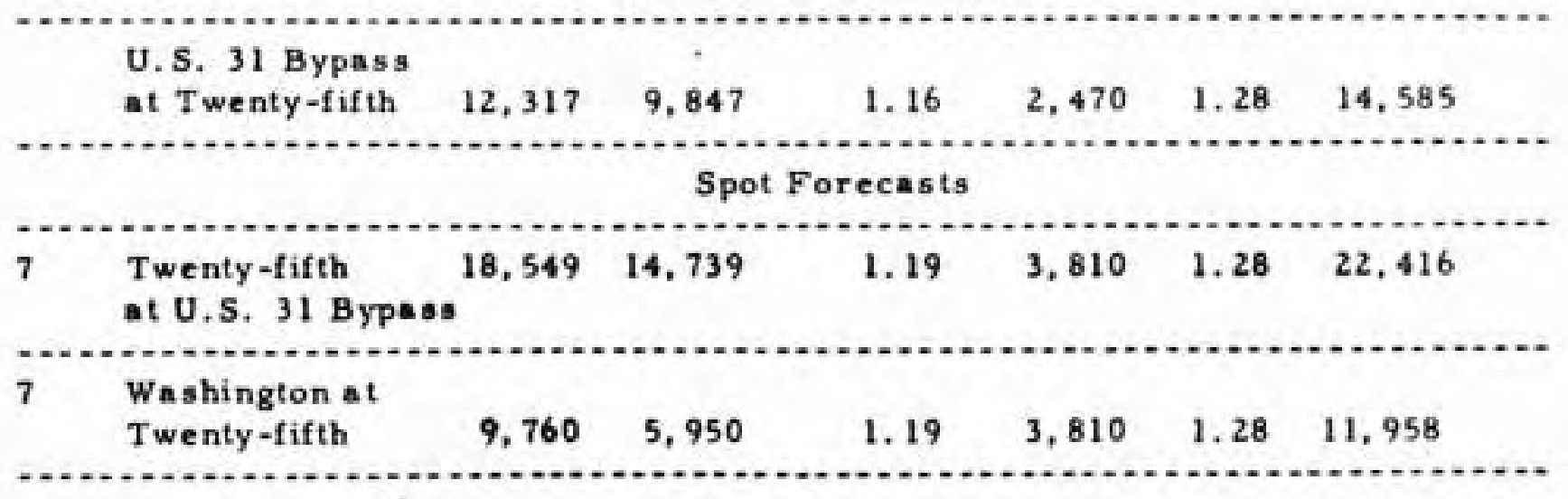




\section{Parking}

Review and recommendations of the central area parking was thoroughly covered in the 1969 and 1970 studies and reports by Barton-Aschman Associates entitled "Columbus Central Area Volumes" and "A Suggested Circulation Plan and Illustrative Parking Program".

The parking control currently in force on the major arterials are noted in Table $3 \mathrm{C}$. One of the most economical means of increasing the capacity and safety on a thoroughfare is by restricting parking either totally or during peak periods provided adequate enforcement ensures compliance. Even though this use of the city's police power sometimes draws considerable criticism it permits the full use of the street for the purpose for which it was intended, to move traffic. The recomended major thoroughfare plan will indicate recommendations concerning parking.

offstreet parking requircments for apartments and other new developments are especially important to ensure the success of planned transportation improvements. When such parking is not required there is a real danger that adjacent thoroughfares will be used for parking instead of providing for moving vehicles as they should.

Driveway openings into major thoroughfares must be controlled both as to their size and location to prevent unnecessary reduction of the capacity of the facility. 


\section{Traffic Control Features}

Application of traffic engineering principles to operation of existing streets and highways provide a means of attaining the most efficient, safe, economical operation without major expenditures. In many cases these applications alone may increase the capacity of the facilities to handle future volumes.

Collection of data on traffic control devices at jntersections, including signal timing, in addition to the information collected in the physical inventory phase of the study, provides the necessary basic data.

Figure $15 \mathrm{C}$ shows the existing intersection traffic control devices in Columbus. T.H. Chastain's report entitled "Columbus Thoroughfares" presents existing signal timing. Suggested changes to improve the efficiency of the system are indicated in the final chapter entitled "Developing the Major Thoroughfare Flan for Columbus". Review of all signal timing should be carefully completed for all sections of the major thoroughfare system prior to expensive construction. This is the assumption made for arriving at the recommended improvements in this study.

Some of the items that can improve the traffic handling capabilities of a thoroughfare are properly placed and maintained guide, warning and regulatory signs. proper, clear and well maintained street markings are also very important to the smooth operation of thoroughfares. Other items that can improve traffic flow are proper signal timing and interconnection of signals when they are closely spaced. Channelization and addition of turning lanes are minor construction items but can greatly enhance the traffic flow characteristics of a facility. Enforcement of no parking areas, restricting use of on-street loading 
zones to off-peak hours and effective application and enforcement of a driveway ordinance all will contribute to the overall efficiency of operation of thoroughfares. 


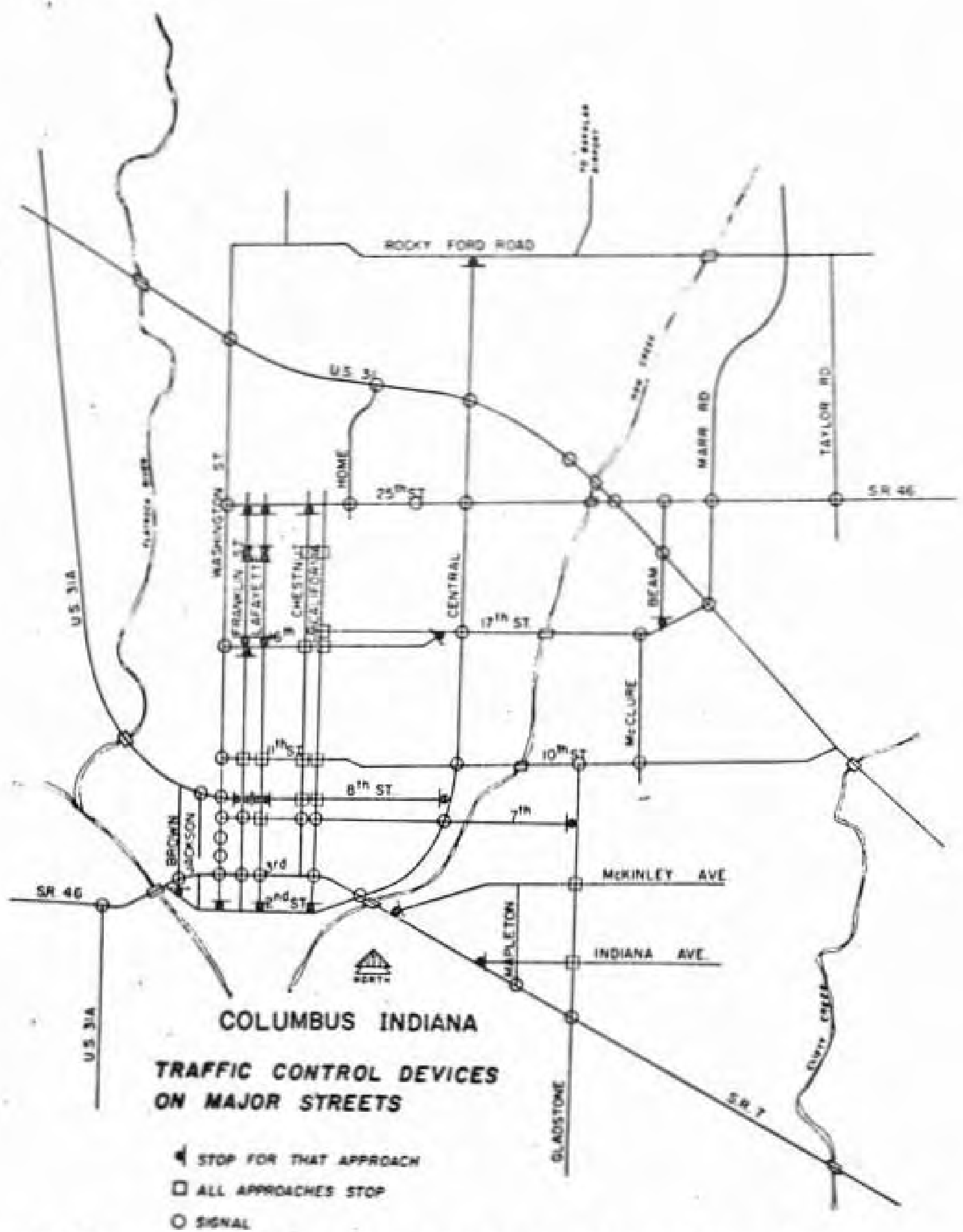

FIGURE 15. TRAFFIC CONTROL DEVICES ON MAJOR THOROUGHFARES 
LAWS AND ORDINANCES

Columbus has recognized the need for planned commity development for many years as evidenced by the excellent planning reports, zoning ordinance and subdivision regulations. All new development in the area must be reviewed and approved in accordance with the above documents.

The purposes of a properly prepared modern master plan, and the accompanying zoning ordinance and subdivision regulations is to provide a positive force for stabilizing the growth and land values of a community and to encourage appropriate compatible development. This guided development is the prime factor that permits proper planning of all public services, including transportation facilities.

The zoning ordinance presently in effect contains certain provisions which may affect the future transportation system. Some of these provisions are as follows:

1. Floodway and flood plain use restrictions

2. Building set back line; 50 feet from right-of-way of primary arterial, 40 feet from the right-of-way of secondary arterial

3. Intersection visibility; fifty foot triangle from line at arterial intersections

4. Industrial park definitions and design controls, such as providing deceleration lanes, channelization, frontage roads, etc.

5. Special use requirements for such uses as airports, public buildings and transportation right-of-way

6. Offstreet parking and loading regulations 
These and other zoning controls regulate the use of land in the city. The regulations will control the type of development in each area thus the zoning ordinance will be significantly involved in the growth of the city. The transportation system in general will be influenced by these provisions and the effects were carefully considered in the plan development phase.

When the procedure and regulations are reviewed and compared to suggested guides from different sources, those currently in effect in columbus substantially exceed all the suggested minimums. The quality of the city administration is such that the necessary re-evaluation of the items to ensure that they remain current with the changing conditions seems assured.

Figure $5 \mathrm{C}$, the land use plan, presents the basic land use locations and classifications as provided by the zoning ordinance. 


\section{FIMANCIAL RESOURCES}

A major thoroughfare study and plan must review the financial resources of a community to permit reasonable, financially feasible recommended improvements and additions to the system. Any plan that doesn't recognize the financial constraint in the planning process can not be implemented, therefore will not be seriously considered in the overall community development.

Information on the historical trend of expenditures for transportation improvements in Columbus and the current bonded indebtedness and the tax base are as follows:

1964 Transportation expenditures

$\$ 51,239$ overlay of streets

18,547 New construction

$\$ 69,786$ Total

1965 Transportation expenditures

$\$ 64,884$ Overlay of streets

38,628 New construction

$\$ 103,512$ Total

1966 Transportation expenditures

$\$ 95,123$ Overlay of streets

10,162 New construction

40,272 Participation in new developments

51,886 Mapping and engineering services

$\$ 197,443$ Total

1967 Transportation expenditures

$\$ 85,139$ Street betterment program

46,971 New construction

14,166 Traffic improvements 
\$ 19,944 Participation in new developments

25,955 Acquisition of right-of-way

514 Mapping

$\$ 192,689$ Total

1968 Transportation expenditures

$\$ 71,438$ Street betterment program

249,777 street and bridge construction

8,149 Traffic improvements

92,609 Participation in new developments

14,341 Engineering services

16,985 Acquisition of right-of-way

$\$ 453,299$ Subtotal

$-106,777$ Participation by Bartholonew County

$\$ 346,522$ Net by city

1969 Transportation expenditures

$\$ 66,746$ street betterment program

59,981 Al1 other

$\$ 126,727$ Total

1970 Transportation expenditures

$\$ 19,462$ Street betterment program

616 Traffic improvements

79,332 New construction

19,589 Participation in new developments

3,107 Engineering services

124,000 Acquisition of right-of-way

$\$ 246,106$ Total

The above information was obtained from Columbus Annual Reports .

In July 1969 the committed bonded indebtedness was $\$ 957,000$. The assessed evaluation was estimated at $\$ 84,027,640$ giving a maximum bonding limit of $\$ 1,680,000$.

Review of the above indicate what has been spent on transportation in the past and the state of bonded indebtedness. The last item is intended to show that if the people 
of columbus feel a project is absolutely necessary it could be financed through municipal bonds.

Information presented on the expenditures since 1964 indicate a minimum of $\$ 200,000$ per year should continue to be available for transportation related projects. This figure should increase directly with the normal increase in the community tax base:

An additional factor that cannot be forecasted is the expected state expenditure in the area. The Interstate 65 construction reduced the through traffic in columbus to a minimum. The construction cost was substantial; however, it must be recognized as a one-shot type expenditure, with ninety percent of the total cost financed from the Highway Trust Fund. After the completion of the Interstate program, funds may be available for assistance on urban area highway construction but to date this is not a fact, except for special projects, therefore was not included in the projection of available funds.

It should be re-emphasized that the community objectives, reflected through positive action by the city administration, dictates the proportion of the tax revenue to be expended in each respective area. 
SOCIAL AND COMMUNITY VALUE FACTORS

To often in the past planning of transportation, sufficient attention has not always been given to other factors of value in the cominity. The transportation system of any community is a strong force in shaping that community. The resulting changes can be either good or bad depending on the considerations given to the community elements during the planning.

Items that must be given consideration during throughfare planning, especially during location of any new facilities, are as follows:

1. Preservation of parks

2. Preservation of recreational areas

3. Preservation of points of historic interest

4. Minimization of disruption to homogeneous areas such as neighborhood units

5. Consideration of school district, to precluaje splitting the district and introducing an additional hazard for the children on their way to school

All of these items are very real when evaluated as a part of the environment of the urban dweller; however, the items are not readily convertable to quantitative terms. They are nevertheless real and must be adequately weighed during the planning process.

The goals and objectives of the entire community are also very real. Sometimes they are also difficult to recognize and reduce to terms that can be utilized as input to the planning process. In Columbus, it is readily evident 
that the overall improvement of the urban amenities that make a community a better place to live and work is the most important goal. This fact was recognized and appropriately considered in the development of the major thoroughfare plan developed as a part of this study. 


\section{ENVIRONMENTAL IMPACT STATEMENT}

Although an environmental impact statement is not required at the planning stage, it was felt to be in the best interest of good planning to consider it at this point, recognizing that the engineers preparing construction plans for individual projects will prepare a more complete detailed statement. A general statement was prepared and is presented below.

The steady past growth of Columbus, Indiana and the forecasted growth of the columbus economic region as presented in the report prepared by Indiana University for the Division of State Planning, Indiana Department of Commerce will necessitate the improvements and additions to the thoroughfare systen as presented in the subject report.

At this point in time public hearings have not been held to permit comments fully reflecting the attitude and opinions of the interested citizens concerning the overall plan. It should be noted that the proposed improvements were recommended with the planner being fully cognizant of the remarks and expressions of concern as expressed in several surveys conducted within the last ten years. These surveys were directed toward determining the ultimate goals and objectives for Columbus, the attaining of which all future efforts and improvements should be directed.

\section{$\underline{\text { Impacts }}$}

Increase in total traffic volume in the columbus area is the basis for recommendation of the improvements herein. The increase will occur irrespective of the action taken 
concerning improvements, therefore additional nuisance and the amount of pollutants released into the atmosphere will be equal with or without said improvements.

The improvements recommended in the thoroughfare plan will increase the safety of travel in the columbus area compared to what would exist without the improvements.

With the addition of the Parkway, portions of the existing flood plain areas could be rezoned for productive use due to the effective utilization of the Parkway embankment as a dike, provided proper flap gates are provided by design in the drainage system.

The Parkway is the only major new facility proposed for the area. The location of the facility adjacent to the White River and Haw Creek should keep disturbance to wildlife to a minimum. Within the approximate established location there are no wild life refuges, important breeding, nesting, or feeding grounds nor is the area the natural habitat for any rare or endangered wildlife species.

The project will not require any change in the water courses, drainage areas, or tributaries of streams, rivers or lakes, thus leaving marine life unaffected. Temporary danger of pollution of streams will exist during construction but will be reduced to a minimum by including and enforcing specifications on the contractor's water sources, methods of handling of embankment construction, control of refuse burning and control of dust and erosion during construction. Construction plans will provide for adequate erosion control measures for the completed facility to preclude pollution due to erosion.

\section{Unavoidable Adverse Effects}

The project recommended in the Columbus Major Thoroughfare Plan will have few adverse effects on the environment and even these few will be minimal. The noise level in the 
area of the new Parkway will be increased slightly; however, because very little grade will be required on the facility and the speed will be on the order of 35-50 miles per hour, all vehicles will be able to operate at a low noise level.

\section{Alternatives}

There are few if any alternatives to the proposed improvements. Continued use of the existing facilities without improvement would impose unreasonable delays on the people of the community in addition to significantly increasing the accident rate.

\section{Short Term and Long Term Effects and Benefits}

The short term effects due to construction of various improvements have been previously discussed. These effects can be satisfactorily controlled during the relatively short construction period by construction specifications and enforcement. The proper design of recommended improvements will provide aesthetically adequate facilities.

The benefits to the immediate columbus area, the economic region, the state and the nation are apparent. Any increase in productivity and income benefits all levels of government.

\section{$\underline{\text { Resources }}$}

The proposed improvements will not involve any irresponsible misuse of resources nor will the environment be effected adversely. 
DEVELOPMENT OF ALTERNATE PLANS

In Columbus, as in other small urban areas, the alternative solutions are limited by the previous investments in the existing system or network of streets and the travel patterns are not subject to change. In the urban areas of less than fifty thousand, freeways are very seldom required to handle the traffic volumes, therefore the alternative solutions consist of application of traffic engineering techniques, such as; widening of existing streets, creation of one-way pairs or new streets on new locations through undeveloped areas.

During the development of the thoroughfare plan for Columbus, the location of deficiencies were such that reascinable alternates to the presented plan were not available. 
DEVELOPING THE MAJOR THOROUGHFARE PLAN

To develop a major thoroughfare plan for a commity requires that the planners establish a scope broad enough to consider the entire thoroughfare and transportation system. To do otherwise initiates and perpetuates a series of isolated, unrelated problem solutions rather than the necessary farsighted system approach to planning for the future development of the area. Proper planning provides the most economical overall system providing the desired level of service throughout, while ensuring compatibility with all the community and environmental subsystems. The objective of this study was to develop estimates of future travel demands in Columbus and based on a comparison of these demands and the capabilities of the existing streets to determine the location and extent of needed improvements to the system. The streets included in the study are those normally classified as major arterials and in a few cases secondary arterials in those cases where secondary arterials actually serve corridor traffic, these streets are referred to herein as major thoroughfares. The street normally classified as collectors and residential or local are discussed on superficially in the study because the basis for their need is for land service and connecting routes or continuity not traffic volumes. The spacing on the collectors and residential and local streets is based on a suggested criteria in the procedural manuals prepared by the National Committee on Urban Transportation. In those areas where minor streets provide continuity or connecting routes to the major thoroughfares, they are included. The 
secondary strect pattern proposed in earlier reports was reviewed and are considered reasonable and should continue to be the guide for future developments.

\section{Recommended Design Criteria}

The recommended cross-section for new major thoroughfares is shown on Fiqure 17C. The dimensions recomended. for the overall right-of-way width and outer separation width are based on review of many contributing factors and provides for the following:

1. Sufficient distance from the natural ground at the property line to the curb of the thoroughfare to effect the required grade transition

2. A "buffer zone" between the adjacent property and the thoroughiare

3. Space for utility locations

4. Space for offstreet utility maintenance

5. Proper sight distance at intersections

6. Space for locating traffic control devices

7. Sufficient distance to provide for driveway, curb and grade transitions

Many existing streets do not have the suggested width of right-of-way or pavement widths and providing of same would be impractical; however, all future extensions should provide the recommended dimensions. The recommended total pavement and lane widths are considered necessary to provide for safe, free movement of traffic. Restriction of widths below those recommended will substantially reduce the traffic handling capabilities of the facility. The detail provided in Figure $16 \mathrm{C}$ furnishes recommended minimum transition lengths when left turn lanes are required at intersections.

To accomodate turning vehicles at intersections without encroachment on adjacent lanes, curb radii should be a 


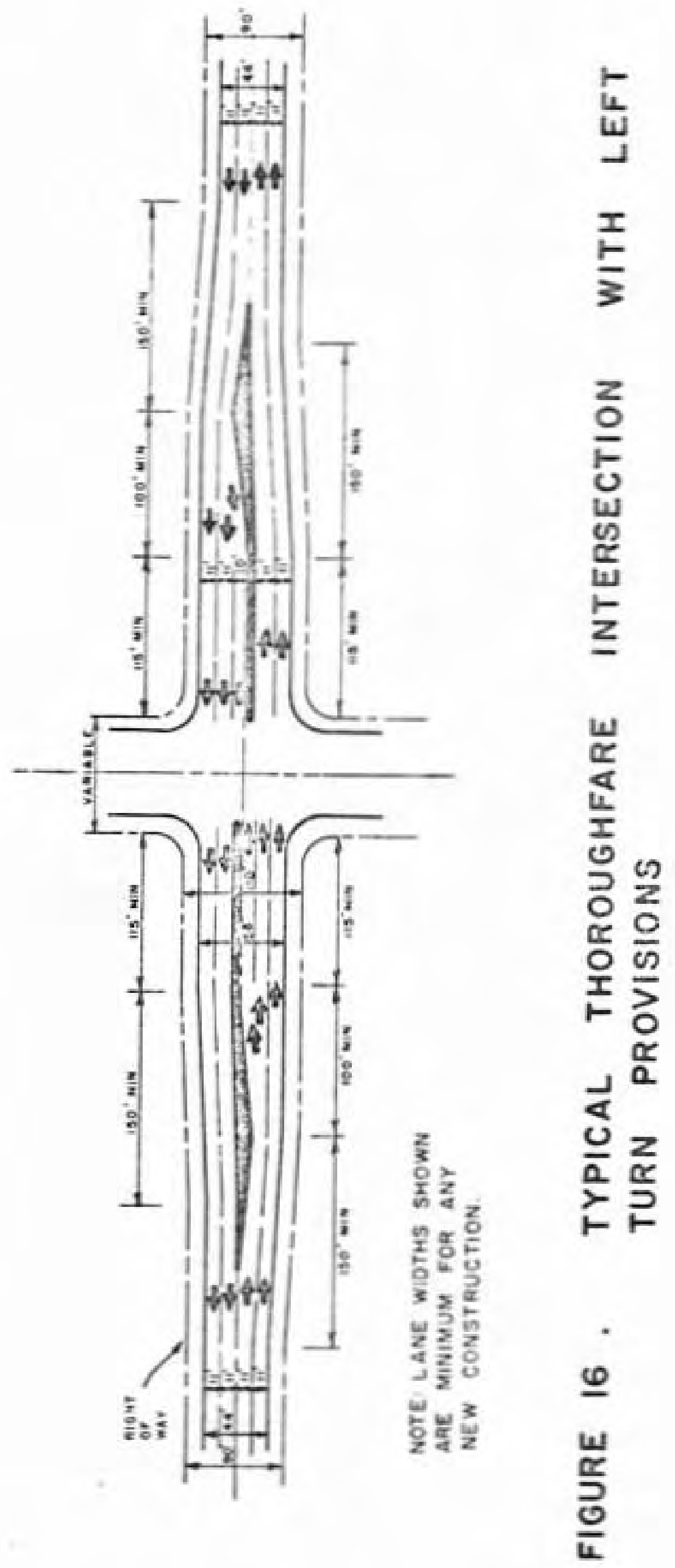




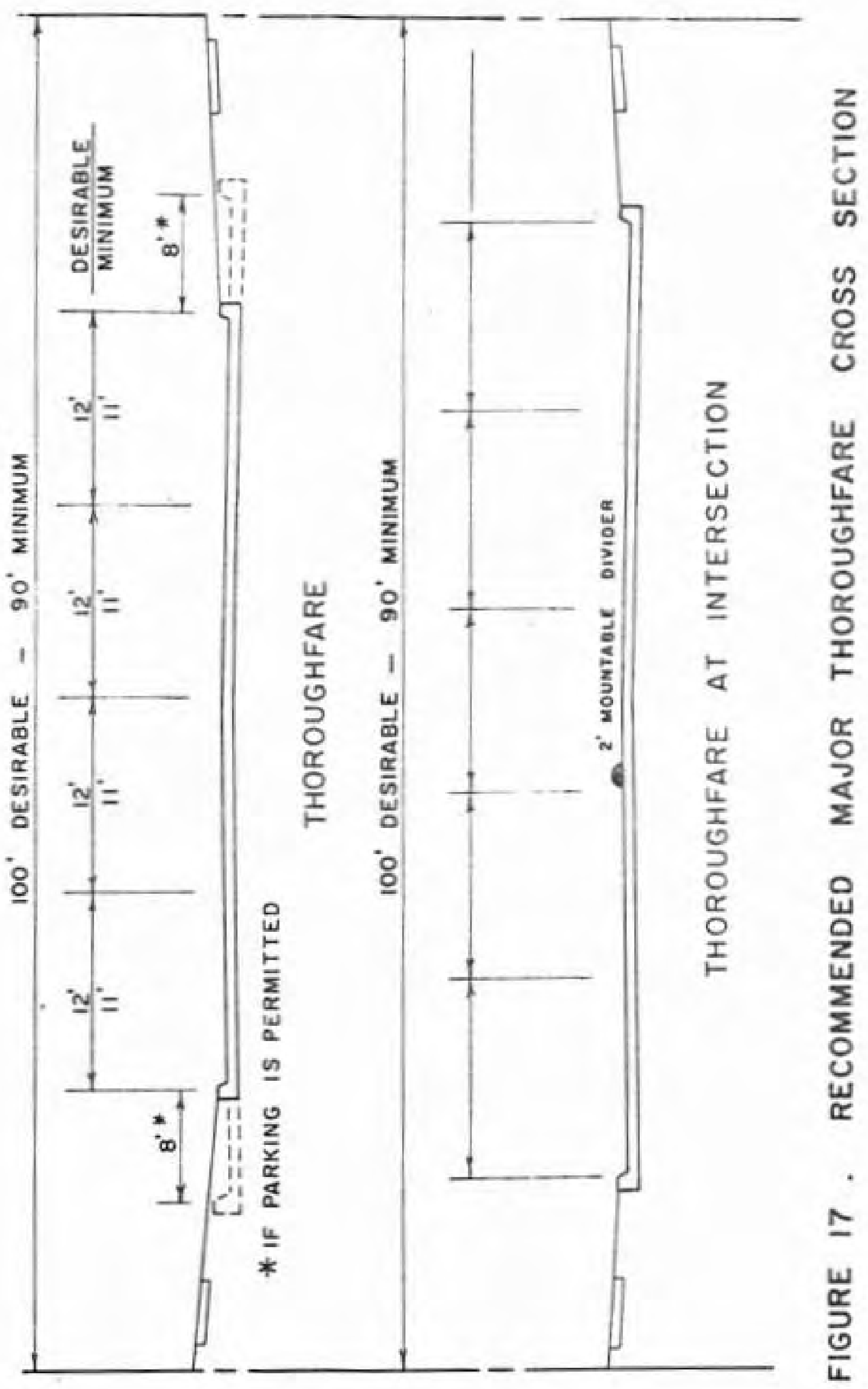


minimum of fifteen feet, preferably twenty-five feet, for intersections with a small percentage of trucks. Intersections with truck and bus traffic should be constructed with thirty foot minimum radii, perferably fifty foot. on newly constructed major thoroughfares, it is recommended that parking restrictions be initially authorized and enforced immediately. This precludes problems at a later date when attempting to impose such restrictions. Areas of the existing system where restrictions of no parking would provide sufficient additional capacity to handle forecasted demand will be discussed individually.

Strict adherence to the provisions of offstreet parking for new high density residential and for commercial development is extremely important to prevent improper use of the major thoroughfares for parking vehicles.

The recommendations in this study are based on forecasted travel demand for 1990 in columbus. The existing physical characteristics of the streets were obtained thus permitting computation of traffic handling ability of the strect. The corridor growth factor procedure was used to provide 1990 forecasted travel demand on the system. Comparison of the forecasted demand to the existing capability of the system to handle traffic provided the location and magnitude of system deficiencies. Alternate methods of relieving these deficiences were then investigated in the following order:

1. Application of traffic engineering restrictive measures, such as removal of parking, channelization, traffic control devices, etc.

2. Minor constructions such as widening, extensions, etc.

3. Installation of one-way streets, etc.

4. Major improvements such as new streets, bridges, etc. 
The final recommended improvements determined in the study are listed in order of priority with respect to traffic demand with the timing of such improvements to be left to the discretion of the policy makers.

The relative priority for the recommended improvements was established by using a straight line forecast for traffic volumes from 1970 to 1990 and thus establishing five year incremental forecasts. These incremental forecasts then indicated the streets with forecasted volumes reaching capacity of the street at the earlier point in time providing the necessary guidance on the needs in relation to travel demand.

\section{Recommended Improvements}

It is never possible and certainly not practical to attempt to ignore work that has been done previous to the study at hand. The direction that past improvements have provided toward development of the future system must be integrated into the proposed future plan. The Arterial. Street Plan for Columbus, Indiana dated April 1963, the reports entitled "A Suggested Circulation Plan and Illustrative Parking Program", "An Evaluation of the Proposed Southern Farkway, Columbus, Indiana" and the "Comprehensive P1an 1985, Columbus, Indiana" were used as reference and were used to determine the present and proposed thoroughfare system presently considered.

The 1990 forecasted travel demand for Columbus indicates several corridors with volumes of sufficient magnitude to require review of the capabilities of the thoroughfares serving those corridors to handle the demand. The forecasted volumes, shown in Figure $14 \mathrm{C}$ and $\mathrm{Table} 8 \mathrm{C}$, are as follows:

1. Corridor 7 - washington Street at the central area $19,552 \mathrm{ADT}$ 
2. Corridor 1 - U.S. 31 Alternate at the intersection with S.R. 46 (W) $-19,761$ ADT

3. Corridor 2 - S.R. 46 (W) just west of U.S. 31 Alternate (S) - 24,379 ADT

4. Corridor 4 - Central Avenue at central area screenline - 16,960 ADT

5. Corridor 6 - S.R. 7 at Haw Creek - 24,011 ADT

6. Corridor 7 - U.S. 31 Bypass at Twenty-fifth Street - 14,585 ADT

7. Corridor 7 - S. R. 46 (E) (Twenty-fifth Street) at U. S. 31 Bypass - 22,116 ADT

Study of the potential problem areas as noted above would seem to indicate several pressing requirements including increased peak hour capacity on California, Chestnut and Second Streets, intersection improvements at S. R. 46 (W) and U.S. 31 A.ternate (S), intersection improvements on Twenty-fifth Street (S.R. 46 (E)) between approximately Marr Road and the High School(Home Avenue), widening of Central Avenue from Tenth to Twenty-fifth, widening of S.R. 46 (W) and U.S. 31 Alternate (S), intersection improvements on U.S. 31 Bypass and service to the new high school.

Viewing the apparent indicated action outlined above from an overall point of view an alternate course of action recomriended by previous studies comes into focus The previously proposed Southern and Eastern Parkway would relieve all the above listed major problem areas, except Central Avenue. Widening would still be required on S.R. 46 (W) and U.S. 31 Alternate (S); however, the indicated additional structural requirements over the river into the central area would be provided on the parkway route instead of the existing routes.

The new high school on Marr Road also will slightly alter travel patterns making improvement of north-south connectors in the vicinity of the school necessary to provide for cross traffic flow to Tenth, Seventeenth, 


\section{v.S. 31 Bypass and Twenty-fifth Street.}

Although only the major thoroughfare travel demand is forecasted, continuity of the secondary street pattern is important for both distribution and disbursement of traffic to the final destination, and for overflow on alternate routes when minor breakdowns in traffic flow occurs on the major thoroughfares. In this respect it is reconsended that several short extensions to the existing system be completed as warranted by new development to satisfy this requirement for continuity and service. These are noted in Table $9 \mathrm{C}$ and the locations shown on Pigure $18 \mathrm{C}$.

Review of the Columbus city nap and the traffic flow map indicates that all traffic in the east-west direction and at least a part of the traffic in the north-south direction with origins and destinations either in the central area or beyond the central area are forced to use routes through the central area. This factor compounds the inherent problems always present in the CBD of a comtunity by adding the extra vehicular burden of these through trips to the working and shopping trips. A major contribution to relief of the circulation and capacity problem throughout the downtown area would be accomplished by providing an alternate or bypass route in reasonably close proximity to the area. This would provide service to the central area while simultaneously relieving the same area of the extra burden of through traffic and, as a third positive factor, provide an additional collection-distribution facility to the area.

The Southern and Eastern Parkways, previously recommended by the "Arterial street Plan for Columbus, Indiana" and by the report "An Evaluation of the Proposed Southern Park" and also by the "1985 Master Plan - Columbus, Indiana", would serve to satisfy the objectives stated. It is reasonable to assume that although the distance from the Taylor and Talley Road areas on the proposcd Parkway to the 
central area is greater by $3 / 4$ to 1 mile than the route using Twenty-fifth Street and Washington Avenue, travel time will increase making the alternate route approximately equal with respect to travel time as traffic volumes on Twenty-fifth street increase. The facility is not warranted at this time throughout the full length; however, stage construction, both with respect to completed cross section and various location sections, can be scaled to the conditions at the time of construction while still making provision for future demand. The cost and priorities of the various sections are presented in Table $10 \mathrm{C}$.

The work currently uncierway in the central area providing a one-way pair of thoroughfares from second to Eleventh Street with construction of completely new streets on Brown and Lindsay and the reconstruction of Jackson Street in the same area, as well as the extension of Eleventh street and a new structure over the river on Eighth Street (U.S. 31 Alternate), will provide considerable relief to the downtown area. These improvements will provide a high level of service for the "super block" and the rest of the urban renewal area. In addition the new thoroughfares will provide needed continuity in the east-west direction on the fringe of the central area, providing an alternate route for Corridor 4 and Corridor 7 traffic to skirt the central area to reach destinations in the southern portion of the central area or to continue west.

The completion of the new high school in corridor 6 , located on Marr Road, should affect a change in traffic flow that will both help in some areas and complicate the overall traffic problem in other areas. Several thoroughfares in the immediate vicinity of the new school should be extended to provide for collection and disbursement of high school traffic in several directions. The extension of Marr Road from McKinley Street to Tenth Street proposed for immediate 
construction would serve this end. Presently, S. R. 7 is the only continuous adequate facility serving the area and the numerous industries in the area now load this facility during peak hours. Additional capacity near the target year of 1990 will have to be provided by the Southern and Eastern Parkway.

Marr Road is not a major thoroughfare under our description; however, adequate service to the new high school will require Marr Road to connect and distribute traffic to the radial major thoroughfares. Marr Road should be widened to thirty-six feet minimum, provicing two moving lanes from the proposed end of the extension at Tenth street to Seventeenth street.

U.S. 31 Alternate and S.R. 46, from west of U.S. 31 Alternate to Interstate 65 , should be widened to four moving lanes. The S.R. 46 widening is programmed for construction in the near future by the Indiana state Highway Comission. If the Southern Parkway is constructed in the reasonably near future then sufficient capacity would be provided over the White River; however, if the parkway is not constructed or constructed at a later date, it will be necessary to widen the existing structure over the white River to six moving lanes to preclude undue delays to the traffic.

Location of proposed Eastern Parkway provides the opportunity of investigation of alternative locations. From a point approximately at U.S. 31 Bypass and Tenth Street, the location to the north could either connect with the partially completed Taylor Road Boulevard or continue to follow Haw creek until reaching a point south of Talley Road, then turning and connecting with Talley Road. The Taylor Road location would better serve the area if development does not preclude its completion to U.S. 31 Bypass. Completion of Taylor Road to the North even as 
stage construction in the near future to U.S. 31 Bypass would provide a needed route.

California and Chestnut Streets should be re-striped for two lanes and parking prohibited during peak hours between Second Street and Twenty-fifth Streets. Forecasted volumes indicate that, through removal of parking, sufficient capacity will be proviced for the foreseeable future. This improvement would serve the industrial complex in the east end of the central area.

Central Avenue traffic volumes will continue to increase requiring two moving lanes in each direction to handle forecasted traffic volumes. This will require widening to forty-four feet minimum, forty-eight feet desirable, between the central area and Twenty-fifth Street.

An alternate interin solution was considered for the south part of the central area. Elimination of parking on one side of Second street from Washington Street to Sycamore street, re-striping for three lanes, and widening of second street from sycamore street to its intersection with S.R. 7 combined with the Indiana State Highway Commission's proposed reconstruction of the S.R. 46 and U.S. 31 Alternate intersection, would make the route through town adequate until near the 1990 target date. The real bottleneck will be the existing structure over the White River, which will be operating at capacity within approximately five to ten years. This interim solution would permit sound financial planning for construction of the Southern Parkway.

In conjunction with the improvement of Second street, constructing Marr Road through to Seventeenth street and realignmert of Tenth Street to cross U.S. 31 Bypass north of the present location to connect with the Taylor Road extension would satisfactorily handle the forecasted traffic until after 1990. The proposed Eastern Parkway could thus be postponed until a later date. 
The estimated construction costs of the above recommended improvements are presented in Table 9C. The order of listing is also the approximate recommended priority for the improvements based on the relative need to handle traffic. Right-of-way costs are not included in the estimates. The exact details for each of the improvements remains for determination by complete, detailed engineering study. Changing conditions make detailed studies at the planning stage wasteful because, as the project advances to the stage of reality, changes would render prior studies obsolete.

Assumptions used in developing estimated costs are as follows:

1. 1,100 pounds per square yard number 4 HAC (ISHC Specification) with 90 pounds per square yard of surface type B HAC for major thoroughfares

2. Drainage structures will be estinated where necessary

3. Tree removal, and preparation of right-of-way is figured in cost

4. Sound existing pavement is assumed to be incorporated into new pavement structure

5. The cost of traffic control devices and markings are not included in the estimates

6. Adjustments to utilities are not included in the estimates

Several intersections should be immediately improved by channelization, additional lanes, and upgrading and/or re-timing of the signal systems. These inclucle the intersections at Twenty-fifth and U.S. 31 Bypass; Second, Third, State and Haw Creek Boulevard; S. R. 46 (W) and U.S. 31 Alternate; Central and Twenty-fifth Street; and Central and Seventeenth Street. 
The intersection of Washington street and Twenty-fizth Street should be re-striped and signed, pernitting two left turning lanes from Twenty-fifth Street to Washington Street.

Two additional items of a general nature are also recommended. First, a continuing program directed toward maintaining all lane markings, on-the-pavement directional arrows, stop lines, and pedestrian crosswalk markings. Second, timing on all traffic control signals should be continuously reviewed and where the type controller does not provide the necessary flexibility for the control of the traffic, steps should be taken to replace the unit.

Widening and new construction on various thoroughrares should be undertaken according to the priority listing in Table 9C.

In addition, it is also recommended that a regular yearly program of resurfacing of major thorougheares be initiated, providing a minimum of ninety pounds per square yard asphaltic concrete or a seal coating on a portion of the system. A reasonable minimum program would include approximately two miles per year with an estimated cost of approximately $\$ 50,000$.

Forecasted 1990 traffic volumes for U.S. 31 Bypass indicate a small increase. If the suggested intersection improvements are completed the facility will be adequate, therefore the estimated cost of widening to four lanes was not included; however, in keeping with the recommendation of four lane throughfares, consideration should be given to the widening after completion of the more urgent needs.

one of the thoroughfares included as a part of the 1963 Arterial street Plan was not included herein. This is the facility in the north part of columbus that was described as part of an outer loop for Indianapolis. The location and the need for this facility should be determined at a later date. 
The recommended improvements, not including the Parkway, are estimated to cost $\$ 1,835,000$. Assuming the continued availability of approximately $\$ 200,000$ annually, the proposed improvements and the recommended maintenance program are well within the financial capabilities of the community. The Parkway construction, however, would probably require financing through a bond issue. 


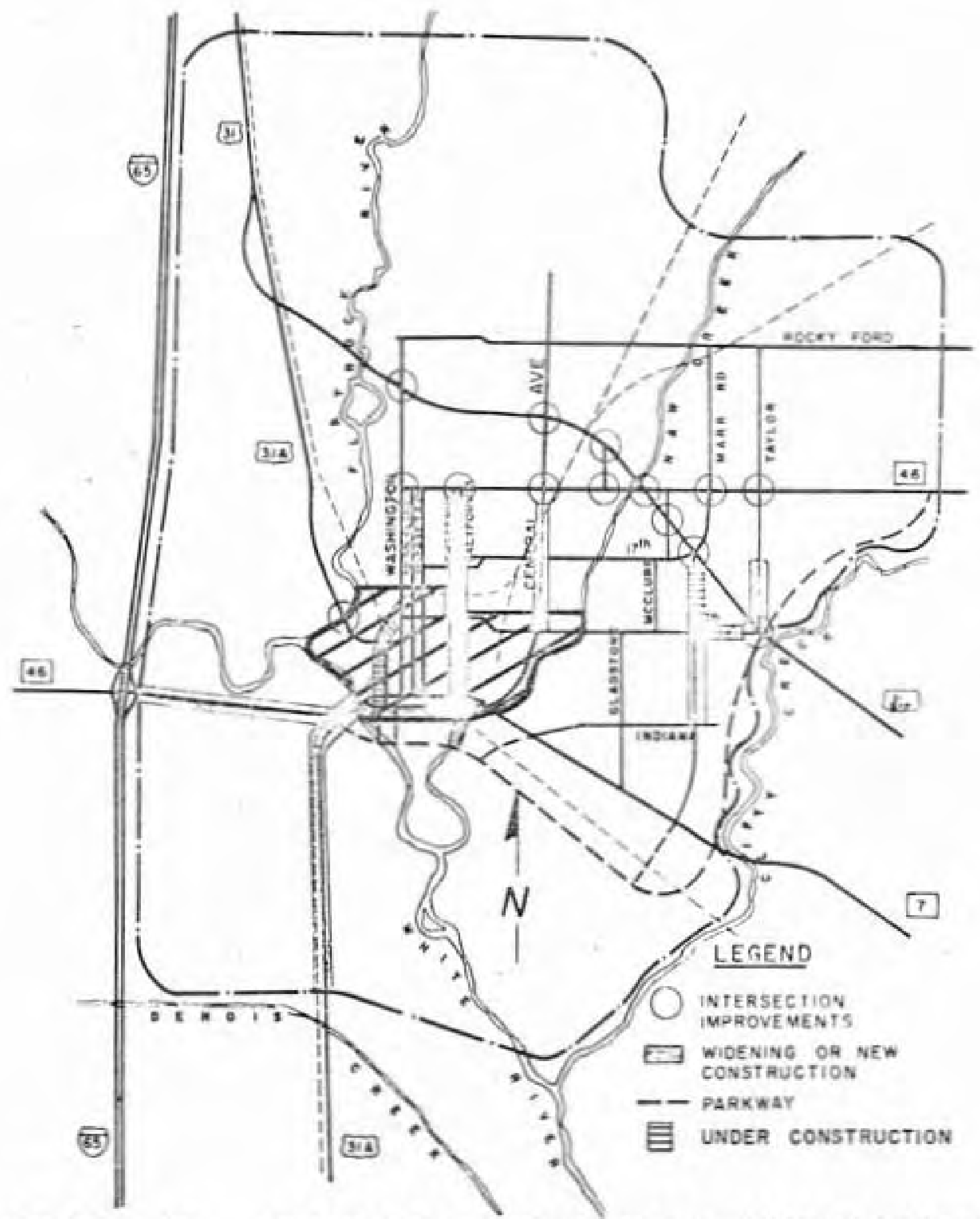

FIGURE 18. COLUMBUS - RECOMENDED IMPROVEMENTS 
Table y Estimaled Cest For Recommended Imprevements - Priseity Fer Censurustion

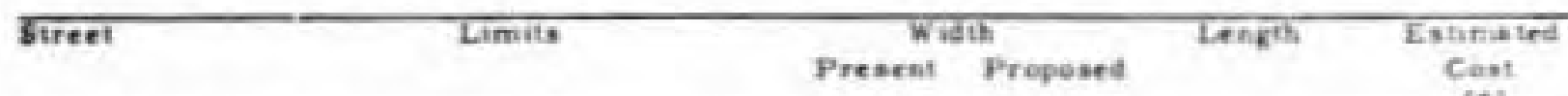

Brow-Lindwy Coencrion (0nder Constrwectuon)

Eigbth Street Bridge (Construction in the Immedate $F$ uture)

Morr Reat

Chesteut

Colufernia

Twertiatio

Toentyluth

U.S. 31 Enow.

Centra!

Marr hect

Taylar keat

Tenth

Secend

Chestanat

U.5. 31 Aliernale

1. 65 te Lindsay (Constractaes in the Immediate Future)

Mckinley to Tenth (Constroction is De immediale Future)

Third te Terstylafn

Third to Twentyluth

At Woskingtos intersection

Wakiextan to Talley Read

Weshingten to Trats

Tron is Teentyfufth

Tents to Sevtsierath

$\begin{array}{lll}* & - \\ i & i & \text { is }\end{array}$

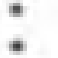

$+$

$\ldots$

....

3. 000 .

3. 700

3,200 .

3.200

2, 500 .

Merr alad to U.S. 11 Bypass 19

Sycamare to S. R. 7 24:

Steond to Third

0

S. 46 is $11 / 2$ miles wouth 26 "

$900^{\circ}$

7. 000 .

(s)

$44^{4}$

46 "

$40^{\circ}$

$40^{*}$

$44^{*}$

1.000

1,000 .

2.000.

126,000

$105,000$.

$217,000$.

$213,002$.

201, 000.

201. 000.

140, 000 .

32,000

596, 000.

Sub Total

$51,835,000$.

Parkeay Eatimate. Southera Parkay

U.S. 31 Alternate to Indiana

Southers Parkway

Eostera Parkway

Euatern Parkway

Indiana to 5.7

5. 7 to U. 5. 31 Bypas:

U.S. 31 Bypass to S. 46

$\begin{array}{llr}0 & 24^{*} & 4,500^{\circ} \\ 0 & 24^{\circ} & 10,500^{\circ} \\ 0 & 24^{\circ} & \$, 600^{\circ} \\ 0 & 24^{\circ} & 5,600^{\circ}\end{array}$

1, 223,000 .

537,000 .

460,000 .

340.000.

Sub Total

5 3, 180,000.

GRAND TOTAL

$5,5,015,000$.

- Stripe and add signa to prehoit parkieg during peak hours.

- Provide for two tanes to tura left.

- 2 Reconotruction of intersections to provide four through ianes plus left iurn Innes at California Street, Chestnut Stree', Cestral Avenue, Deam Street, Haw Creek Blvd., Marr Road and Talley Road, and prohibut left turns at U.S. 31 Bypass.

Q.*. Reconstruetion of intersections te prowide twe theough lanes plas left turn lanes at Washington Street, Central Avenue, Twenty-fifth Street, Beam Street, Mart Road and Ienth Street. 